\title{
The Effect of Focus and Phrase Position on East Norwegian Lexical Tonal Accents
}

\author{
Niamh E. Kellya Rajka Smiljanić ${ }^{b}$ \\ aDepartment of English, American University of Beirut, Beirut, Lebanon; \\ ${ }^{b}$ Department of Linguistics, University of Texas at Austin, Austin, TX, USA
}

\begin{abstract}
Two experiments examined the acoustic correlates of the disyllabic tonal accent contrast in the Trøndersk dialect of Norwegian, and how narrow focus and phrasal position shape the contrast. Production results showed that both tonal accents have a high-low (HL) pitch contour, with different timing. In narrow focus, the pitch contrast was enlarged through asymmetrical $F_{0}$ changes. When at the right edge of an accent phrase (AP), the accents were shown to have a higher $\mathrm{L}$, lower AP H\% tone, shorter stressed vowel, and longer final vowel. The alignment changes reflected tonal crowding while segmental modifications were due to the phrase-final lengthening in AP-final position. This work contributes to the literature on prosodic typology as well as on the implementation of prosodic focus and sentence intonation in languages with lexical pitch contrasts.
\end{abstract}

(c) 2017 S. Karger AG, Basel

\section{Introduction}

Tonal accent is a prosodic pattern found on stressed syllables (e.g., Beckman, 1986; Hyman, 2009). Yip (2002) describes accentual languages as "a particular type of language in which tone is used in a rather limited way, with one (or perhaps two) tone melodies, either lexically linked to particular TBUs [tone-bearing units] or perhaps attracted to a syllable selected as prominent by rhythmic principles" (p. 260). Hualde (2012) defines them further as "a class of stress languages where words contrast in the tonal melody that is associated with the stressed syllable" (p. 1335). In such a language, 2 segmentally identical words can thus be distinguished by the tonal contour only: bønder "farmers" (accent 1) and bønner "beans" (accent 2) (the segments of both words are pronounced /'bøn:ər/) is a minimal pair in the Oslo variety of Norwegian. Tonal accent languages differ from tone languages such as Mandarin, Vietnamese, or Zapotec languages because the tonal contrast is restricted to the primary stressed syllable, meaning that a word can only have one tonal accent (an accent cannot also occur on a secondary stressed syllable), whereas in a tone language, any syllable can have a specific pitch contour. Furthermore, in the majority of varieties

\begin{tabular}{l}
\hline KARGER \\
$\begin{array}{l}\text { E-Mail karger@ } @ \text { karger.com } \\
\text { www.karger.com/pho }\end{array}$
\end{tabular}

\footnotetext{
Niamh Kelly

Department of English, American University of Beirut PO Box 11-0236, Riad El Solh

Beirut 11072020 (Lebanon)

E-Mail nk114@aub.edu.lb or niamhkelly632@gmail.com
} 


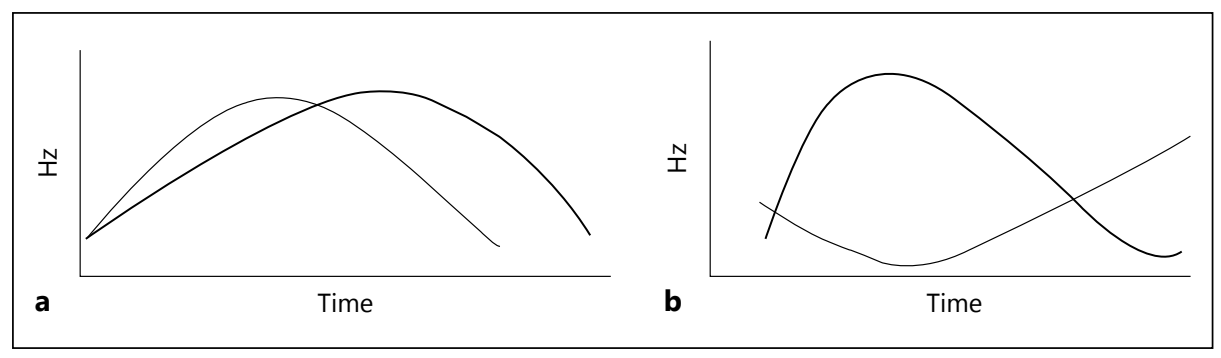

Fig. 1. Hypothetical contours showing a difference in timing (a) or tonal makeup (b) between 2 accents.

of Norwegian and Swedish, the tonal accent contrast cannot occur on monosyllabic words. Varying instantiations of this phenomenon are found in typologically related and unrelated languages, such as Norwegian and Swedish (e.g., Gårding, 1973; Bruce, 1977; Fintoft, 1987), Lithuanian (Senn, 1966), Latvian (Derksen, 1966; Karins, 1996), Japanese (Pierrehumbert and Beckman, 1988), and some varieties of Korean (e.g., Kim, 1988), Basque (Hualde, 1991), Serbian and Croatian (Smiljanić, 2006), and Dutch and German (Gussenhoven, 2004).

The nature of the tonal accent contrast has been studied extensively, both impressionistically and experimentally, for a number of different dialects of Swedish and Norwegian (e.g. Storm, 1884; Bjerrum, 1948; Vanvik, 1957; Fintoft, 1970; Gårding, 1973; Gårding and Lindblad, 1975; Bruce, 1977; Elstad, 1978; Lorentz, 1981; Riad, 1998; Kristoffersen, 2000; Van Dommelen, 2002; Van Dommelen and Nilsen, 2003; Segerup, 2003, 2004; Almberg, 2004; Gussenhoven, 2004; Riad, 2006). The 2 contrasting accents are referred to as accent 1 and accent 2 . The contrast between the 2 tonal accents can be one of tonal makeup or timing (see Fig. 1, showing hypothetical contours where the difference between the accents is either in timing, early vs. late peak [Fig. 1a] or in tonal makeup, low-high vs. high-low, HL, contour [Fig. 1b]).

The makeup and phonetic realization of each of the tonal accents differ across the Scandinavian language varieties (Fintoft, 1970; Gårding, 1973). For example, in Norway, in some dialects accent 2 has the tonal makeup of an HL contour over the stressed syllable whereas in other dialects, accent 2 has a low-high contour (e.g., Almberg, 2004). Even within the dialect groups, the phonetic realization of the contour of each accent differs. Gårding (1973) describes the typology of Swedish dialects based on the accent contours, specifically, how many $\mathrm{F}_{0}$ peaks each accent has and the timing of these. For example, in the south of Sweden the dialects have 1 peak in each accent, where accent 1 words have their peak early in the stressed syllable and accent 2 words have their peak late in the stressed syllable. In contrast, further north in Gotland, an island off the east coast of Southern Sweden, accent 1 words have their peak late in the stressed syllable, and accent 2 words have their peak late in the post-stress syllable. Fintoft (1970) provides similar descriptions of dialects in Norwegian based on the number of peaks and tonal timing. Despite these differences, Fintoft (1970) makes the generalization that the main peak is always earlier in accent 1 than accent 2 , and that accent 1 never has more peaks than accent 2 . The first comprehensive acoustic analysis of the tonal accent contrast in Stockholm Swedish revealed that both tonal accents are $\mathrm{HL}$, but the difference between accent 1 and accent 2 was in the timing of the $\mathrm{F}_{0}$ fall in 
relation to the stressed syllable, whereby it was aligned later for accent 2 than accent 1 (Bruce, 1977). Phonologically, the L is associated with the stressed syllable for accent 1 words, while the $\mathrm{H}$ is associated with the stressed syllable for accent 2 words. This difference is what explains the timing difference between the accents (Bruce, 1977).

Gårding (1973) divides Swedish dialects into "single-peaked" and "doublepeaked." In single-peaked dialects, both tonal accents have a single pitch peak or high tone. In double-peaked dialects, a high tone is added when the accents are focused, such that accent 2 words end up with 2 peaks, hence the name "double-peaked."

In addition to regional variation, the tonal accent contrast can be affected by pragmatic focus and sentence level prosody (Bruce, 1977; Kristoffersen, 2000; Mixdorff et al., 2010). These postlexical phenomena can impact segmental duration and determine distribution and identity of tonal events as well as their exact realization. Little work has directly examined how pragmatic focus and higher level sentential intonation affect the accent contrast in Norwegian. The question of interest is how much variation in the features that define the phonological tonal contrast can be allowed due to focus and sentence intonation while preserving the lexical contrast itself. Accordingly, the goal of the present study is twofold. First, we want to examine how the tonal contrast is implemented in Trøndersk, an understudied variety of East Norwegian spoken in the Trøndelag region in central Norway. Second, we investigate how sentence intonation (position in utterance) and focus (broad vs. narrow [contrastive] focus) impact the realization of the tonal accent contrast.

\subsection{East Norwegian Tonal Accent}

East Norwegian comprises a group of dialects spoken in the southeast and central regions of Norway (Kristoffersen, 2000). Figure 2 shows the Trøndelag region, where Trøndersk is spoken, highlighting Trondheim (the capital city of the region). The thick gray line highlights the whole area - Trøndelag and the southeast region around Oslo, labeled Østlandet. East Norwegian dialects spoken in this area are generally referred to as low-tone dialects, where accent 1 has been described as consisting of a low tone (L) and accent 2 of an HL contour (Almberg, 2004).

Different analyses have been proposed for the tonal accent contrast in Trøndersk, the region of interest. The contrast has been described as a difference in tonal makeup, with accent 1 being L and accent $2 \mathrm{HL}$, thus aligning the Trøndersk variety with other low-tone varieties of East Norwegian (Nilsen, 1992). In contrast, other studies have suggested that the difference lies in the timing of the $\mathrm{F}_{0}$ contour, with both accents having an HL lexical tonal accent, thus making this variety distinct from others in the region (L vs. HL; Fintoft, 1970). According to Fintoft (1970), accent 1 already reaches its $\mathrm{F}_{0}$ minimum (L target) in the (initial) stressed vowel, while accent 2 has its initial $\mathrm{H}$ tone in the middle of the stressed vowel, and falls from there. In addition, the unstressed (second) vowel tends to be significantly longer in accent 2 words (Fintoft, 1970). Examining the Trondheim variety (the capital city of the region where Trøndersk is spoken), Wetterlin (2010) described accent 1 as having an L tone associated with the stressed syllable and accent 2 as having an $\mathrm{H}$ tone associated with the stressed syllable, and accent 1 having a steeper fall than accent 2 . In this variety, the $\mathrm{L}$ tone is found earlier in accent 1 , where it occurs during the first syllable, while in accent 2 it occurs in the second syllable. A similar contour alignment difference was described for a variety spoken in the west of the Trøndelag region (Van Dommelen and Nilsen, 2003). While the 2 accents had a similar overall contour (HL), the difference between them was in the timing of the $\mathrm{F}_{0}$ 


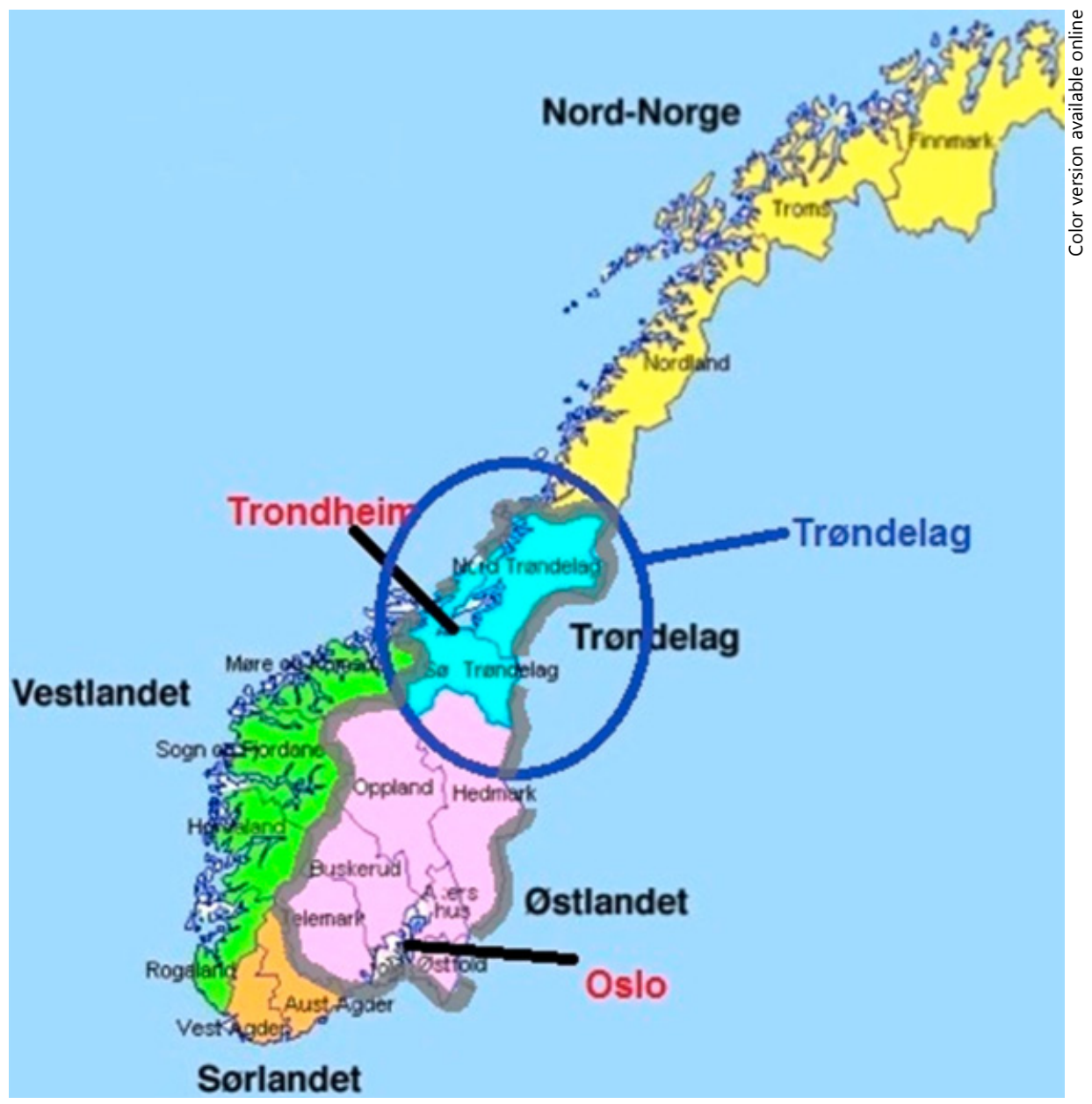

Fig. 2. Map showing the Trøndelag region (Bookcoverimgs.com, 2012).

fall and in the following rise to a phrasal boundary tone, which both occurred earlier for accent 1 than accent 2. Examination of the tonal accent contrast in Oppdal, in the south of the Trøndelag region, similarly revealed that both accents have an HL contour, with an earlier timing in accent 1 than in accent 2 (Kristoffersen, 2006b). In both Oppdal and Trondheim, the initial $\mathrm{H}$ is in the stressed syllable for both accents, while the following $\mathrm{L}$ is associated with the stressed syllable in accent 1 and the post-stressed syllable in accent 2 (Fintoft, 1970; Kristoffersen, 2006b). These results highlight the diversity of the tonal accent systems across the dialects in the region, varying in contour timing or tonal makeup. The current study addresses the lack of agreement in describing the tonal accent in the Trøndersk dialect. To that end, the present study examines in detail the tonal contrast produced by 10 speakers from the region. This will allow us to examine if there is an initial $\mathrm{H}$ in accent 1 and provide insight into whether the difference between the 2 accents is one of timing or tonal makeup. 


\subsection{East Norwegian Sentence Intonation}

Sentence intonation affects how the tonal contrasts are realized (e.g., Bruce, 1977; Pierrehumbert and Beckman, 1988; Gussenhoven and Bruce, 1999; Riad, 2006). Higher-level intonation is known to influence lexical tonal contrasts not only in languages with tonal accent such as Norwegian and Swedish, but also in languages with lexical tone, that is, where each syllable carries a specific pitch contour. For instance, in Kammu, a tone language spoken in Laos, when a lexical HL tone is followed by a sentence-final boundary $\mathrm{H}$ tone, the sentence-final boundary tone is not fully realized and instead surfaces as a level or falling contour (Karlsson et al., 2010). The authors conclude that the realization of the lexical tone supersedes the realization of the sentence intonation tone. In Thai, on the other hand, Abramson (1979) observed that the lexical tones are modified by sentence intonation although the contrasts are still preserved. Lin (2004) found that lexical tones are distinguished by their $\mathrm{F}_{0}$ contour while sentence intonation is expressed through $\mathrm{F}_{0}$ range in Mandarin.

With regard to tonal accent languages, work on Swedish showed that while the range of the rise or fall in the tonal accent contours can be affected by sentence intonation, the contrast is preserved (Hadding-Koch, 1961, 1962). Bruce (1977) conducted extensive analyses on the tonal accents in Stockholm Swedish in different types of sentence contexts (position, prominence, following accents). When words with a tonal accent are in sentence-final position, they exhibit a sharp drop in $\mathrm{F}_{0}$ on the last syllable, meaning that the accent contour is affected by a boundary tone (Bruce, 1977). Furthermore, Gårding (1973) also presents contours of accents in a variety of Swedish dialects, showing that when an accented word is produced with question intonation, there is often a final rise added to the end of the accent contour. These results show that the tonal accent contour can be realized differently due to higher-level sentence intonation.

East Norwegian sentence intonation is extensively described by the Trondheim Model (Fretheim, 1981, 1982). In this model, an utterance is composed of intonational phrases (IP) which are further composed of accent phrases (AP), specified for accent 1 or 2 depending on the accent of the word that heads the AP (e.g., Haugen and Joos, 1952; Fretheim, 1987a; Fretheim and Nilsen, 1989; Fretheim, 1991). Each AP starts with a primary stressed syllable at the left edge and includes any number of unaccented syllables before the next stressed syllable which is the head of the following AP. The right edge of the AP is delimited by a high boundary tone $(\mathrm{H} \%)$ (Fretheim, 1987b; Nilsen, 1989; Kristoffersen, 2000), as shown in Figure 3. While this work provides important information about East Norwegian prosodic structure, none of these studies examined how IP- and AP-level boundary tones interact with the lexical tonal accent and whether this interaction impacts their realization. One brief mention of the effect of the number of syllables in the AP on $\mathrm{F}_{0}$ implementation in East Norwegian is in Teig (2001). He states that the contour of a 2-syllable AP differs from that of a 1-syllable AP (presumably a stressed monosyllabic word, which is described in the literature as carrying accent 1 ), suggesting that tonal crowding impacts the realization of lexical and phrasal tones. Specifically, there is a more marked drop to the lexical L when there is a second, unstressed syllable in the AP. The interaction of the tonal accent and sentence intonation in Trøndersk will be explored in the current study. 


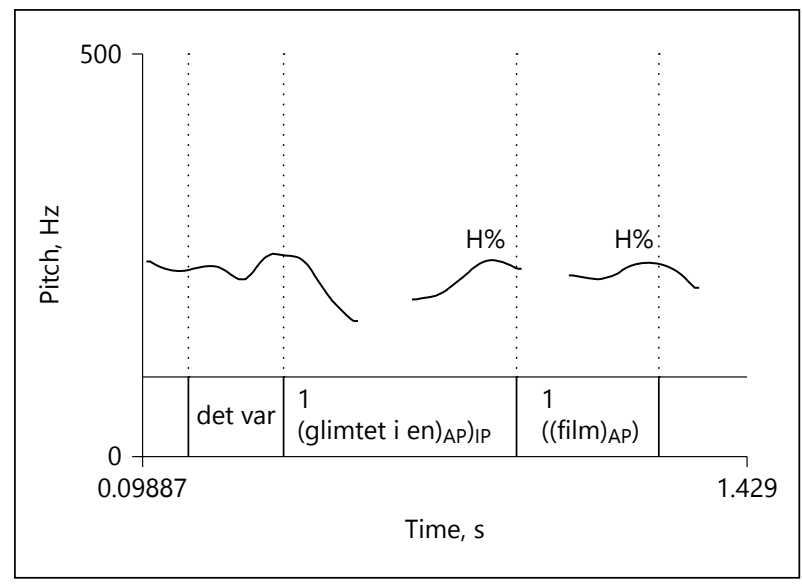

Fig. 3. Norwegian sentence intonation. The accented words are marked for their tonal accent (here, both glimtet and film are accent 1 ), and the end of each accent phrase is marked with a high boundary tone, $\mathrm{H} \%$.

\subsection{Focus Realization in East Norwegian}

While there are various ways in which focus can be defined (related both to its meaning and scope), here we use the term "narrow focus" to denote what is also known as contrastive focus (Chafe, 1976; Rooth, 1985; Gussenhoven, 2005; Selkirk, 2008; Katz and Selkirk, 2011). In this sense, a constituent under contrastive focus relates to a set of alternatives that are shared between the interlocutors. In many languages, focus is realized prosodically, leading to changes in the intonational pattern of a sentence. This is particularly interesting for languages where pitch movement is used lexically, that is, tone languages and tonal accent languages, including Norwegian. Numerous studies across prosodically different languages have documented the effect of narrow and contrastive focus on the realization of the $\mathrm{F}_{0}$ contour and segmental duration (Ladd, 1978; Gussenhoven, 1984; Beckman and Edwards, 1994; Ladd, 1996; Sluijter and van Heuven, 1996; Campbell and Beckman, 1997; Remijsen and van Heuven, 2005; Zhang et al., 2006; Arvaniti et al., 2006; Prieto, 2014; Peters et al., 2014). In German, for instance, in narrow focus, intonational pitch accents are lowered in prenuclear position and deaccented in the postnuclear position (Féry and Kügler, 2008). Narrow focus in English and Dutch is realized by a higher $\mathrm{F}_{0}$ peak and longer segments (Pierrehumbert, 1980; Cooper et al., 1985; Eefting, 1991; Cambier-Langeveld and Turk, 1999; Xu and $\mathrm{Xu}, 2005)$. A later alignment of the tonal targets in narrow focus was found for some varieties of Dutch and German (Peters et al., 2014).

Narrow focus can also change the shape of the lexical tonal accents. In Swedish, the single-peaked dialects expand the pitch range on the target word to signal narrow focus. In contrast, double-peaked dialects add a pitch gesture after the stressed syllable in focus - hence the name "double-peaked" (referring to accent 2 words in these dialect types), meaning that the contour itself is actually different in narrow focus (Bruce, 2005). When a word is focused, the focal $\mathrm{H}$ (the second peak) actually creates a high plateau connecting to the initial $\mathrm{H}$ of a following accented word. In languages with lexical tone, an expanded pitch range (Pierrehumbert and Beckman, 1988; Xu, 1999; Remijsen, 2002; Fournier et al., 2006; Scholz, 2012) and greater articulatory force (Chen, 2010) are often used to mark narrow focus. Interestingly, even closely related tonal languages exhibit differences in focus realization, such that postfocal $\mathrm{F}_{0}$ range 
compression is found in Beijing Mandarin but not in Taiwan Mandarin or Taiwanese (Chen et al., 2009).

Narrow focus impacts segmental durations, as mentioned above for English and Dutch (Cooper et al., 1985; Eefting, 1991). Similar segmental lengthening was found in tonal dialects of Dutch and German (Peters et al., 2014). In a dialect of West Limburgian, Peters (2007) found that durational differences between the tonal accents (one accent had consistently longer syllables than the other accent, in addition to different $\mathrm{F}_{0}$ contours) were increased in nuclear position. In Swedish, phonologically long segments were lengthened more than short segments in focus, thus exaggerating the phonological contrast between short and long vowels and consonants (Bruce, 1977; Bannert, 1979; Bruce, 1981). Also in Swedish, the unstressed syllable following the stressed syllable was lengthened under focus (Heldner and Strangert, 2001).

Similar to the findings that phonologically short and long vowels were more distinct in narrow focus, tonal accent contrasts can also be enhanced. Smiljanić (2003) found that in the Belgrade variety of Serbian, narrow focus caused asymmetric changes in the alignment of high and low tonal targets between the lexical accents, leading to an enlarged contrast between the accents in this condition. In a slightly different way, focus enhances the lexical tonal accent contrast in the Venlo dialect of Dutch, where the contrast only surfaces when target words are focused or utterance final (Gussenhoven and van der Vliet, 1999).

In East Norwegian, narrow focus is marked by a high tone at the right edge of the AP (Fretheim, 1987b; Nilsen, 1989; Kristoffersen, 2000). This tone contributes to the lexical item being perceived as focused even when the focus marker is a few syllables beyond the focused word (Abrahamsen, 2004), if the focused word is not the only element in the AP. A similar pattern whereby the focus tone is not necessarily realized on the focused word is found in languages such as Bengali (Hayes and Lahiri, 1991) and Greek (Arvaniti et al., 2006). For East Norwegian, the original $\mathrm{H} \%$ of the AP and the focus $\mathrm{H}$ tone combine, causing the $\mathrm{H} \%$ at the right edge of the AP (as seen in Fig. 3 ) to have a higher $\mathrm{F}_{0}$ (Fretheim, 1987b; Fretheim and Nilsen, 1989; Kristoffersen, 2000).

Narrow focus was also found to affect segmental duration in Norwegian, with accent 1 words having longer vowel, syllable and word duration (Mixdorff et al., 2010). Finally, alignment differences were noted in tonal targets in broad and narrow focus. An earlier AP H\% alignment was found in narrow focus compared to broad focus for accent 1 words (Koreman et al., 2009), while Mixdorff et al. (2010) found earlier AP H\% alignment in both accents. It appears there is no description, however, of how narrow focus impacts the height or alignment of the lexical tones themselves, and whether narrow focus enhances or reduces the tonal accent contrast. (By "lexical tones," we make no claims thus far about a phonological analysis of the tonal accents, since in particular the question of an initial $H$ tone in accent 1 is examined in the current study; rather, for now this term refers to the tones that surface on the words, rather than higher-level phrasal tones.)

\subsection{The Current Study}

The current study expands on previous research by conducting detailed acoustic analyses examining a number of acoustic cues in a larger number of sentences and speakers in the Trøndersk variety (Kelly, 2015), with the goal of characterizing the tonal accent contrast in this variety. The stimuli used in this study control for the effect of sentence intonation thereby investigating the lexical and intonation effects on tonal 
contours separately. Specifically, we examine the tonal accents in 2 conditions (broad focus vs. narrow focus and AP-medial vs. AP-final), while also controlling for neighboring consonants and vowel quality. It is hypothesized that both accents will have an HL contour and the tones in accent 2 will have a later timing in relation to the segmental string than accent 1 . The current study will provide evidence about whether accent 1 is HL or L (Kristoffersen, 2006b) by examining the $\mathrm{F}_{0}$ contour of the sentence-initial words (the anacrusis) that precede the target words. We predict that given enough segmental material, the initial $\mathrm{H}$ of the HL in accent 1 will be observed. The results will further provide an account of the impact of sentence-level intonation on tonal accent contrasts. To this end, we investigate how narrow focus is realized in Trøndersk, and how this impacts the accent contrast. In the current experiment, we elicit a narrow (contrastive) focus on the target word by contrasting it with a later word in the sentence. Based on previous work, it is hypothesized that in narrow focus, both accents will have a wider pitch range, earlier and higher AP $\mathrm{H} \%$ tone, and longer segments. If indeed narrow focus affects the tonal accent contrast itself, it is hypothesized that accent 1 will have an earlier alignment of $\mathrm{F}_{0}$ landmarks in narrow focus than in broad focus, while accent 2 will have an even later alignment in narrow focus, resulting in contrast enhancement.

Finally, we compare how the contrast is realized in AP-medial versus AP-final position. It is hypothesized that the AP-final boundary $\mathrm{H} \%$ tone will be realized on the target word when in AP-final position, thus adding an extra tone to this unit. It is expected that the closer presence of the AP-final $\mathrm{H} \%$ tone will cause an earlier alignment of the lexical tones in relation to the syllable, compared to AP-medial position. This immediately following $\mathrm{H} \%$ tone may also cause the lexical $\mathrm{L}$ tone $\left(\mathrm{F}_{0}\right.$ minimum) to not be as low as in the AP-medial condition, thereby making the $\mathrm{F}_{0}$ slope less steep.

\section{Experiment 1: Accent Realization in Broad and Narrow Focus}

\subsection{Methods}

\subsubsection{Participants}

Ten native speakers ( 6 female, 4 male) of the Trøndersk dialect, aged 18-45 years, participated in the experiment. They were recruited by posters and fliers around the campus of the National University of Science and Technology (NTNU), Trondheim, and were paid for their participation. Before the recording session, they filled out a language background questionnaire. Only speakers from towns south and west of Trondheim who grew up speaking Trøndersk at home were included in the study. Their parents were also native speakers of this dialect. Figures 4 and 5 and Appendix A (Table 1) shows speaker details.

\subsubsection{Materials}

All target words were disyllabic and had initial stress. The stressed vowel was always /i:/ (when long, or /I/ when short), to control for intrinsic pitch and duration differences across vowel categories. Only sonorant consonants appeared next to the stressed vowel, for example, "limet "the glue" (accent 1) and "minne "memory" (accent 2). All target words and sentences are listed in Appendix B (Table 6). There were 5 unique target words for accent 1 , each produced 3 times, giving 15 tokens. Due to the constraints on vowel, stress, word class, and consonant type, only 2 target 


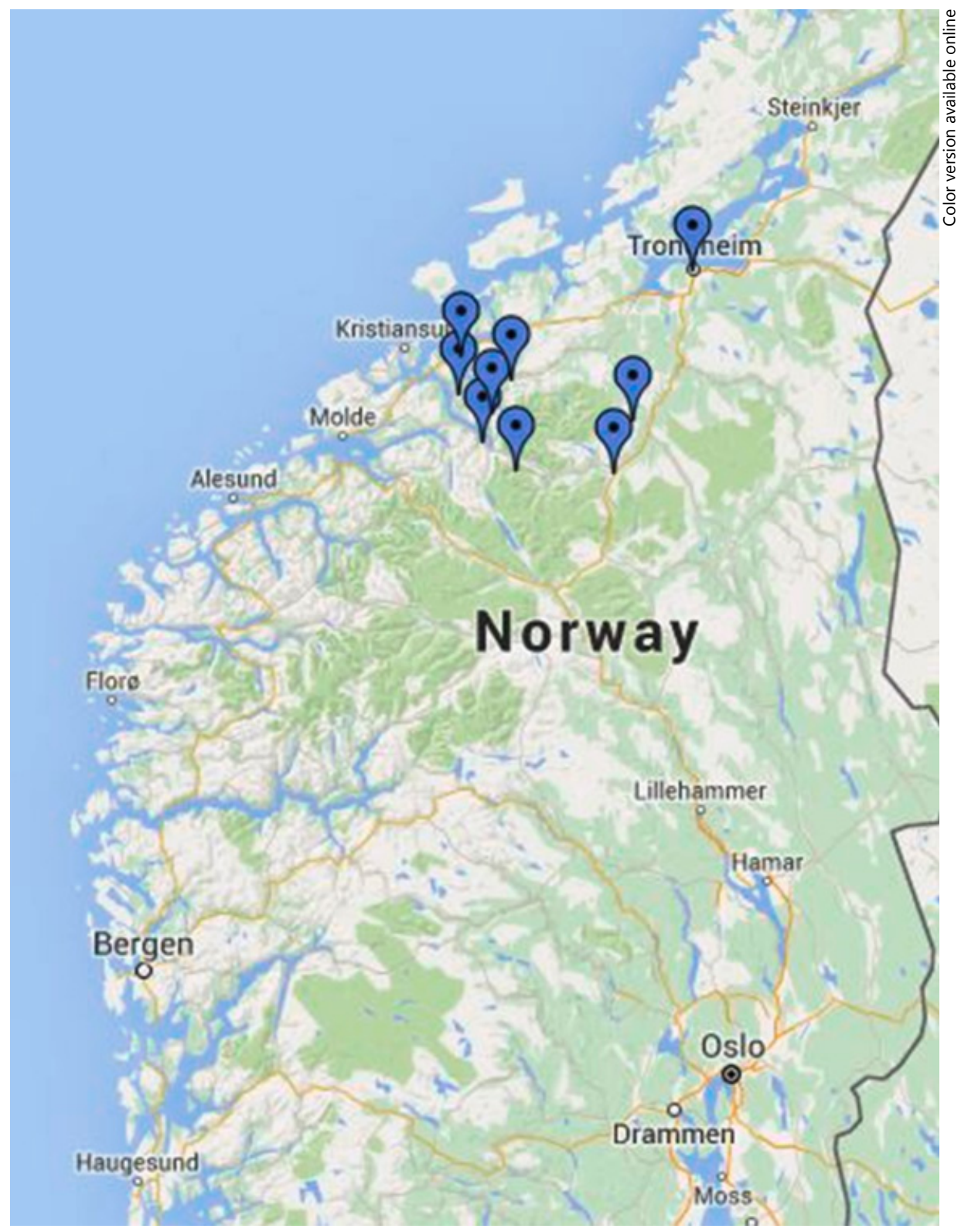

Fig. 4. Map showing speakers' hometowns - zoomed out (Google Maps, 2016).

words could be used for accent 2 . One word was produced 7 times and the other was produced 8 times, also giving 15 tokens. While this leads to a somewhat unbalanced design, it was preferred over introducing other segmental and suprasegmental confounds. Importantly, when the same statistical tests were run on a subset of the data, where only 2 accent 1 tokens and the equivalent number of accent 2 tokens were 


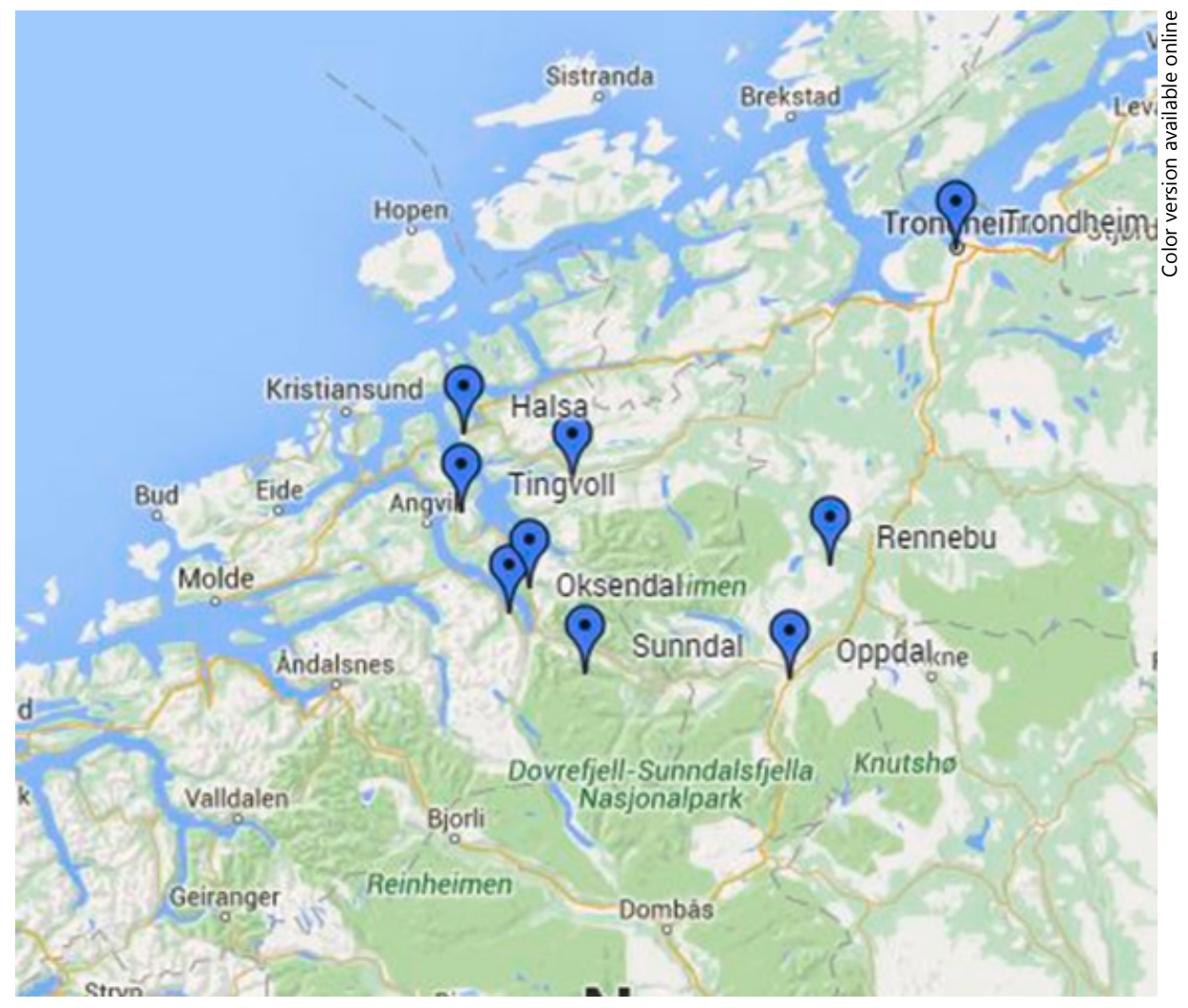

Fig. 5. Map showing speakers' hometowns - zoomed in (Google Maps, 2016).

compared, the results for all measures reflected exactly what was found for the overall results (that is, the 2 accents and the 2 conditions differed from each other in the same measures as in the full data set). This suggests that the different number of distinct tokens had no bearing on the current findings. This yielded a total of 600 tokens (15 tokens $\times 2$ accents $\times 2$ conditions $\times 10$ speakers). For accent 1 , four of the 5 target words contained a phonologically long vowel followed by a short consonant (V:C), and 1 of the 5 had a short vowel followed by a long consonant (VC:). For accent 2, one of the target words had V:C and one VC:. (This difference in vowel length across accents was taken into account when timing measurements were made and are also discussed in the Results.)

The target words were produced in sentences to elicit either a broad (noncontrastive) or narrow (contrastive) focus reading. For the broad focus condition, a content word a number of syllables after the target word was contrasted with a word at the end of the sentence. This ensured that the target word did not receive narrow focus. In the narrow focus condition, the target word was contrasted with a word at the end of the sentence (see below for example sentences). The words intended to be focused were written in bold. Participants were instructed to read the sentence silently to be sure of the meaning (in terms of which words contrasted with one another) and then to read 
them aloud with the pronunciation that matched the meaning. In both conditions, the target word was preceded by 2 or 3 unstressed syllables, which were outside of the AP containing the target word (Kristoffersen, 2006b). The target words were also followed by 2 unstressed syllables in the same AP, to ensure that the target word did not carry the $\mathrm{H} \%$ boundary tone that marks the right edge of the AP in East Norwegian (Fretheim, 1987a). Example sentences for all conditions are below, with the target words in bold. The prosodic structure is labeled according to the Trondheim Model (Fretheim, 1981). $(\mathrm{AP}=$ accent phrase, $\mathrm{IP}=$ intonational phrase, $\mathrm{IU}=$ intonational utterance. $)$

Accent 1, broad focus:

Det var glimtet $\mathrm{i}$ en film, men ikke i et stykke.

$\left.\left(\left(\text { Det var }\left({ }^{1} \text { glimtet-i-en }\right)_{\mathrm{AP}}\right)_{\mathrm{IP}}\left(\left({ }^{1} \mathrm{FILM}\right)_{\mathrm{AP}}\right) \text {, men itj i et }\left({ }^{2} \mathrm{STYKKE}\right)_{\mathrm{AP}}\right)_{\mathrm{IP}}\right)_{\mathrm{IU}}$

"There was the flash in a film, but not in a play."

Accent 1, narrow focus:

Det var glimtet $\mathrm{i}$ en film, men ikke brannen.

$\left.\left(\left(\text { Det var }\left({ }^{1} \text { GLIMTET-i-en }\right)_{\mathrm{AP}}\right)_{\mathrm{IP}}\left(\left({ }^{1} \text { film }\right)_{\mathrm{AP}}\right) \text {, men itj }\left({ }^{1} \mathrm{BRANNEN}\right)_{\mathrm{AP}}\right)_{\mathrm{IP}}\right)_{\mathrm{IU}}$

"There was the flash in a film, but not the fire."

Accent 2, broad focus:

Det var et minne i en film, men ikke i et stykke.

$\left.\left(\left(\text { Det var et }\left({ }^{2} \text { minne-i-en }\right)_{\mathrm{AP}}\right)_{\mathrm{IP}}\left(\left({ }^{1} \mathrm{FILM}\right)_{\mathrm{AP}}\right) \text {, men itj i et }\left({ }^{2} \mathrm{STYKKE}\right)_{\mathrm{AP}}\right)_{\mathrm{IP}}\right)_{\mathrm{IU}}$

"There was a memory in a film, but not in a play."

Accent 2, narrow focus:

Det var et minne i en film, men ikke en drøm.

$\left.\left(\left(\text { Det var et }\left({ }^{2} \mathrm{MINNE}-\mathrm{i}-\mathrm{en}\right)_{\mathrm{AP}}\right)_{\mathrm{IP}}\left(\left({ }^{1} \text { film }\right)_{\mathrm{AP}}\right) \text {, men itj en }\left({ }^{1} \mathrm{DR} \varnothing \mathrm{M}\right)_{\mathrm{AP}}\right)_{\mathrm{IP}}\right)_{\mathrm{IU}}$

"There was a memory in a film, but not a dream."

\subsubsection{Procedure}

The sentences were presented in slide format, in a randomized order. Different focus conditions were interspersed randomly. Additional sentences examining the accents in AP-final position (experiment 2), and examining the accents on monosyllabic words (not discussed here) were interspersed randomly with the current sentences. We did not include other distractor sentences to avoid making the recording sessions prohibitively long. The order of the sentences was kept the same for all listeners. Any possible effect of order on production was thus expected to affect both focus conditions and accent types equally. The participants were in control of when to move to the next slide. The sentences were written in the standard Bokmål orthography and also in a transcription of Trøndersk to encourage them to use the Trøndersk dialect. They were instructed to speak in a casual manner as they would at home. The recordings were done using Adobe Audition at a sampling rate of $44.1 \mathrm{kHz}$. The experiments took place in the phonetics studio at NTNU in Trondheim, Norway.

In order to ensure the naturalness of the productions and the intended focus reading, the first author worked with a native speaker who studies intonation in Trøndersk and who listened to a number of recordings to ensure the first author was correctly hearing which words were focused. Any recordings that did not correspond to the intended reading were not included in the analyses. This only happened in 14 sentences across 4 speakers. 


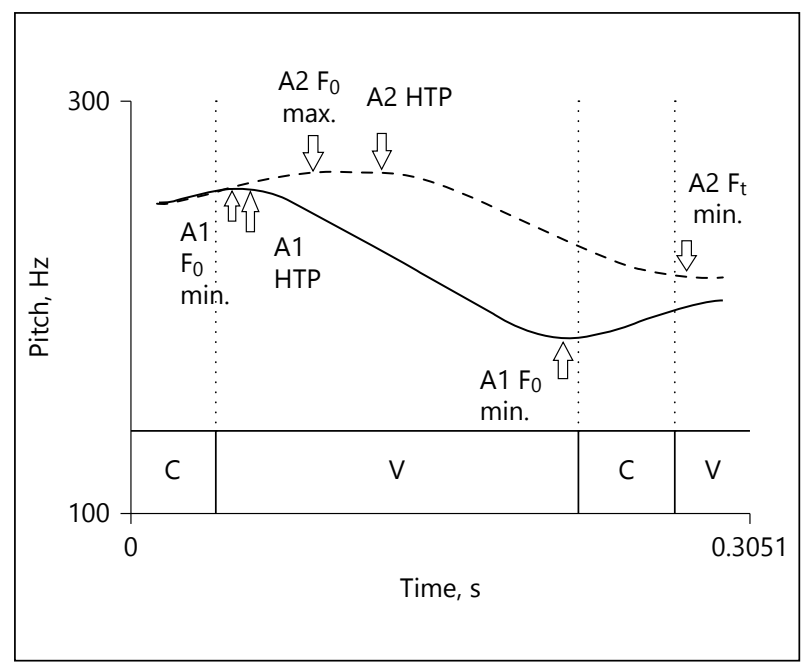

Fig. 6. Schematized Trøndersk accent 1 (solid) and accent 2 (dashed), showing $\mathrm{F}_{0}$ maximum, $\mathrm{F}_{0}$ minimum and HTP.

\subsubsection{Measurements and Analysis}

Expanding on previous findings, a number of $\mathrm{F}_{0}$ and segmental measurements were taken using Praat (Boersma and Weenink, 2011). Here, we focus on the height and alignment of tonal events on the target word and at the end of the AP, and the duration of the stressed syllable.

The specific measurements included: stressed vowel and consonant duration, unstressed vowel duration, height and alignment of the first $\mathrm{F}_{0}$ maximum $(\mathrm{H})$, the $\mathrm{F}_{0}$ turning point (HTP - the point where $\mathrm{F}_{0}$ starts to fall after a high plateau) and the following $\mathrm{F}_{0}$ minimum (L) occurring on the target word, slope of the rise to the initial $\mathrm{H}$, slope of the fall between $\mathrm{H}$ and $\mathrm{L}$, boundary slope from $\mathrm{L}$ to $\mathrm{AP} \mathrm{H} \%$, and the height and alignment of the following $\mathrm{F}_{0}$ maximum occurring at the end of AP. All measurements were made on the target word, except for the accentual phrase high tone (AP $\mathrm{H} \%$ ) measurements, which were made on the final syllable in the AP. The first $\mathrm{F}_{0}$ maximum of some accent 1 words occurred before target word onset, and in these cases it was measured where it occurred. Figure 6 illustrates where the alignment measurements were taken on the 2 accents.

These measurements will allow us to examine how the tonal contrast is realized as well as how it is impacted by pragmatic focus (experiment 1) and by tonal crowding through the interaction with the AP tone (experiment 2).

Vowel onset was determined as the point at which the spectrogram darkened and the amplitude in the waveform increased, indicating an increase in intensity. Vowel offset was determined as the point at which the spectrogram lightened for the start of the following sonorant consonant. Consonant offset was the onset of the final unstressed vowel.

The initial $\mathrm{H}$ was the first $\mathrm{F}_{0}$ maximum between the beginning of the sentence and the end of the stressed syllable of the target word. The $\mathrm{L}$ was the $\mathrm{F}_{0}$ minimum that followed the initial $\mathrm{H}$. The alignment of $\mathrm{F}_{0}$ minimum and HTP was measured from vowel onset and then divided by the combined duration of the vowel and postvocalic consonant. This was done to control for speaking rate differences. The 
duration of the vowel and following consonant were combined because some target words had $\mathrm{V}: \mathrm{C}$ and some $\mathrm{VC}$ :, so combining these allowed for pooling of timing measures regardless of phonological vowel length. Because $\mathrm{F}_{0}$ maximum often occurred before word onset or vowel onset, especially for accent 1 words, the timing of this measure was divided by word duration. This was to compensate for speaking rate but also for onset type differences, since some target words had a complex onset, and some had not.

Slope of the rise was the pitch difference between the beginning of the $\mathrm{F}_{0}$ rise to the $\mathrm{F}_{0}$ maximum, divided by the duration between these 2 points. This was measured to determine whether both accents had a rise to an initial $\mathrm{H}$ tone. Slope of the fall was the pitch difference from $\mathrm{H}$ to $\mathrm{L}\left(\mathrm{F}_{0}\right.$ maximum to minimum), divided by the duration between the 2 points. Boundary slope was the $\mathrm{F}_{0}$ difference between the turning point from $\mathrm{L}$ to $\mathrm{AP} \mathrm{H} \%$, divided by the duration between these 2 tonal events. This was measured in order to examine whether narrow focus affects the pitch contour leading to the AP H\% tone. AP H\% timing was measured in milliseconds from the AP $\mathrm{H} \%$ tone to the AP boundary. This was done to determine whether this AP tone's realization is affected by narrow focus. Stressed vowel duration was examined separately for long and short vowels. With regard to the tonal accent characteristics, it was hypothesized that accent 2 has a later tonal alignment than accent 1 . It was further predicted that in narrow focus, accent 1 would have an earlier tonal alignment and accent 2 a later tonal alignment. Furthermore, the prediction was that the AP tone will be higher and earlier in the narrow focus condition. Finally, it was predicted that segment duration would be increased in the narrow focus condition.

A mixed model multiple linear regression analysis was conducted using the lmerTest package in $\mathrm{R}$ ( $\mathrm{R}$ Development Core Team, 2008). The independent variables were accent ( 1 or 2 ) and focus realization (broad or narrow) (so the model was accent $\times$ realization) and the dependent variables were: $\mathrm{F}_{0}$ maximum height and alignment, $\mathrm{F}_{0}$ minimum height and alignment, $\mathrm{F}_{0}$ maximum turning point (HTP), stressed vowel duration, unstressed vowel duration, AP $\mathrm{H} \%$ height and timing (from the AP boundary), slope of the rise to the initial $\mathrm{H}$, slope of the fall between $\mathrm{H}$ and $\mathrm{L}$, and boundary slope from L to AP H\%. Speaker and word were included as random effects.

\subsection{Results}

Average results for each dependent variable can be found in Appendix C (Tables 7-18). Figure 7a shows overlapping contours for accent 1 words by speaker, and Figure $7 \mathrm{~b}$ shows accent 2 by speaker, both in broad focus. Figure $8 \mathrm{a}$ and $\mathrm{b}$ shows each of the accents by speaker, both in narrow focus. These figures are time normalized, showing the full AP (target word and the following 2 unstressed syllables), and were produced using measurements from the program ProsodyPro $(\mathrm{Xu}, 2013)$ in Praat.

Figure 9a shows separate pitch tracks for each speaker, comparing accent 1 and accent 2 in broad focus. Figure $9 \mathrm{~b}$ shows each speaker's accents in narrow focus. It can be seen that in broad focus, the 2 accents have similar HL contours, but accent 2 has a later alignment of the $\mathrm{F}_{0}$ contour and a high plateau. It can also be seen that accent 2 has a higher $F_{0}$ minimum than accent 1 . In narrow focus, there is a wider pitch range and later timing of accent 2 . The stressed vowel is also longer in narrow focus. In these figures it is clear that the $\mathrm{H}$ in accent 2 is always later than the $\mathrm{H}$ in accent 1. For some speakers, the $\mathrm{H}$ is also higher in accent 2 than accent 1. Table 2 shows the statistical test results for each dependent measure. The mixed model 


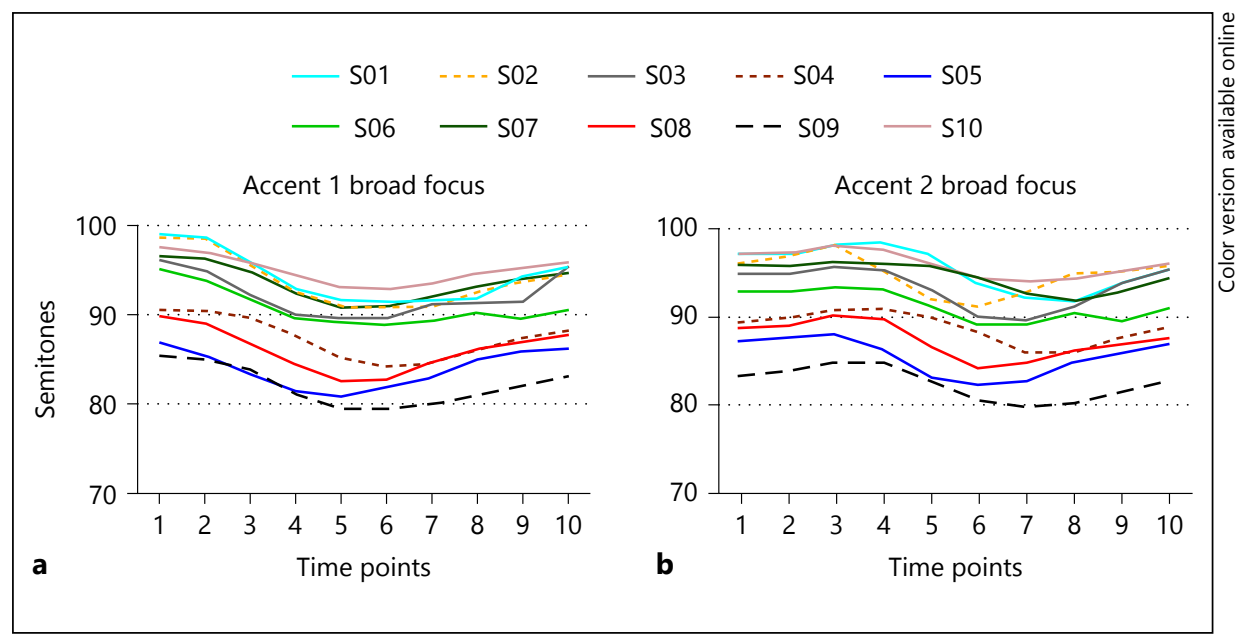

Fig. 7. a Contours of accent 1 words in broad focus for each speaker. b Contours of accent 2 words in broad focus for each speaker.

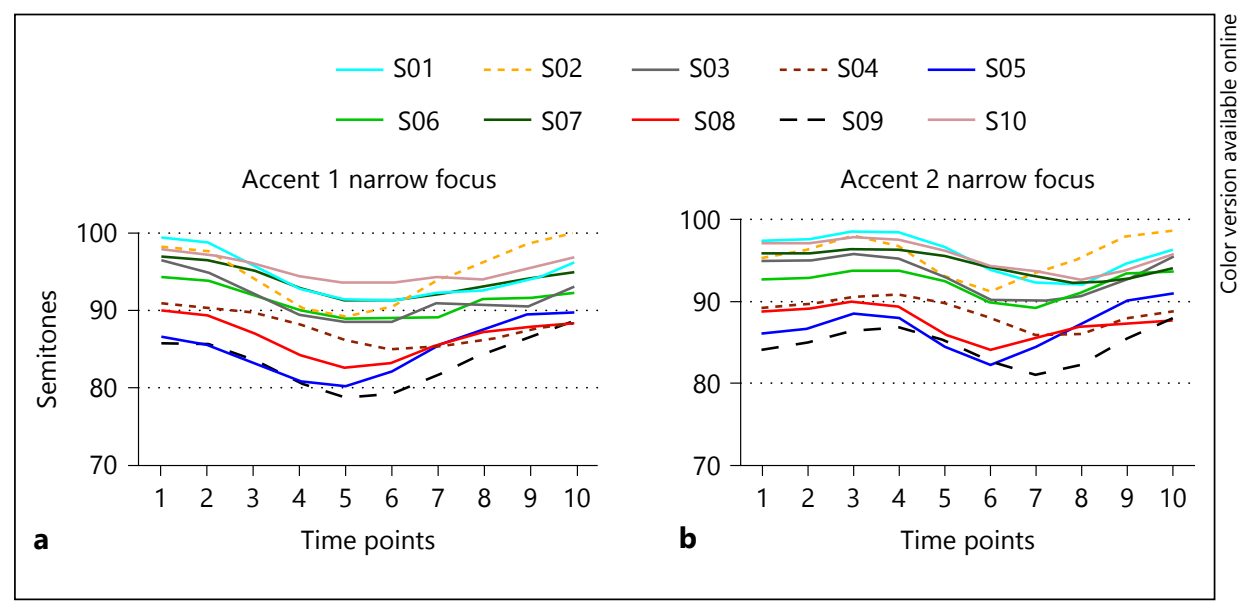

Fig. 8. a Contours of accent 1 words in narrow focus for each speaker. b Contours of accent 2 words in narrow focus for each speaker.

multiple linear regression had accent and focus realization as the independent variables. Accent refers to the difference in any measure between accent 1 and accent 2 . Focus refers to the difference between the broad and narrow focus productions. The reference level for accent is accent 1 , and the reference level for focus is broad focus. The polarity of the coefficient shows whether accent 2 or the narrow focus realization has a higher or lower value for a particular measure, in comparison to accent 1 , or the broad focus realization, respectively. If the coefficient is negative, accent 2 or the narrow focus realization has a lower average value (or earlier alignment) for this measure

$\begin{array}{llll} & \begin{array}{l}\text { Phonetica 2017;74:193-230 } \\ \text { DOI: } 10.1159 / 000453270\end{array} & \text { Kelly/Smiljanić }\end{array}$




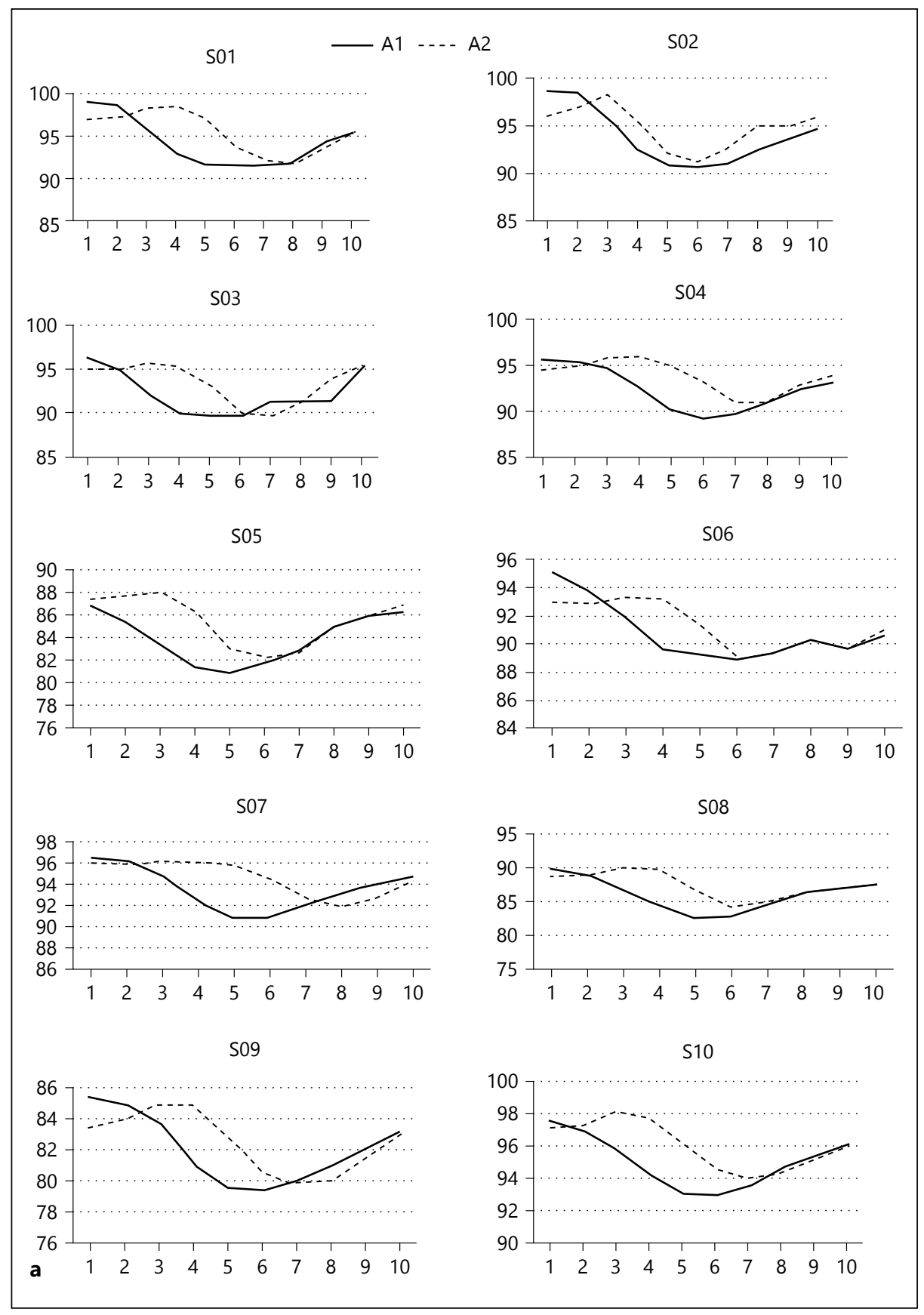

Fig. 9. a Accent 1 and accent 2 in broad focus by speaker. The $x$-axis indicates semitones, the $y$-axis time points. b Accent 1 and accent 2 in narrow focus by speaker. The $x$-axis indicates semitones, the $y$-axis time points.

(For figure $9 b$ see next page.) 


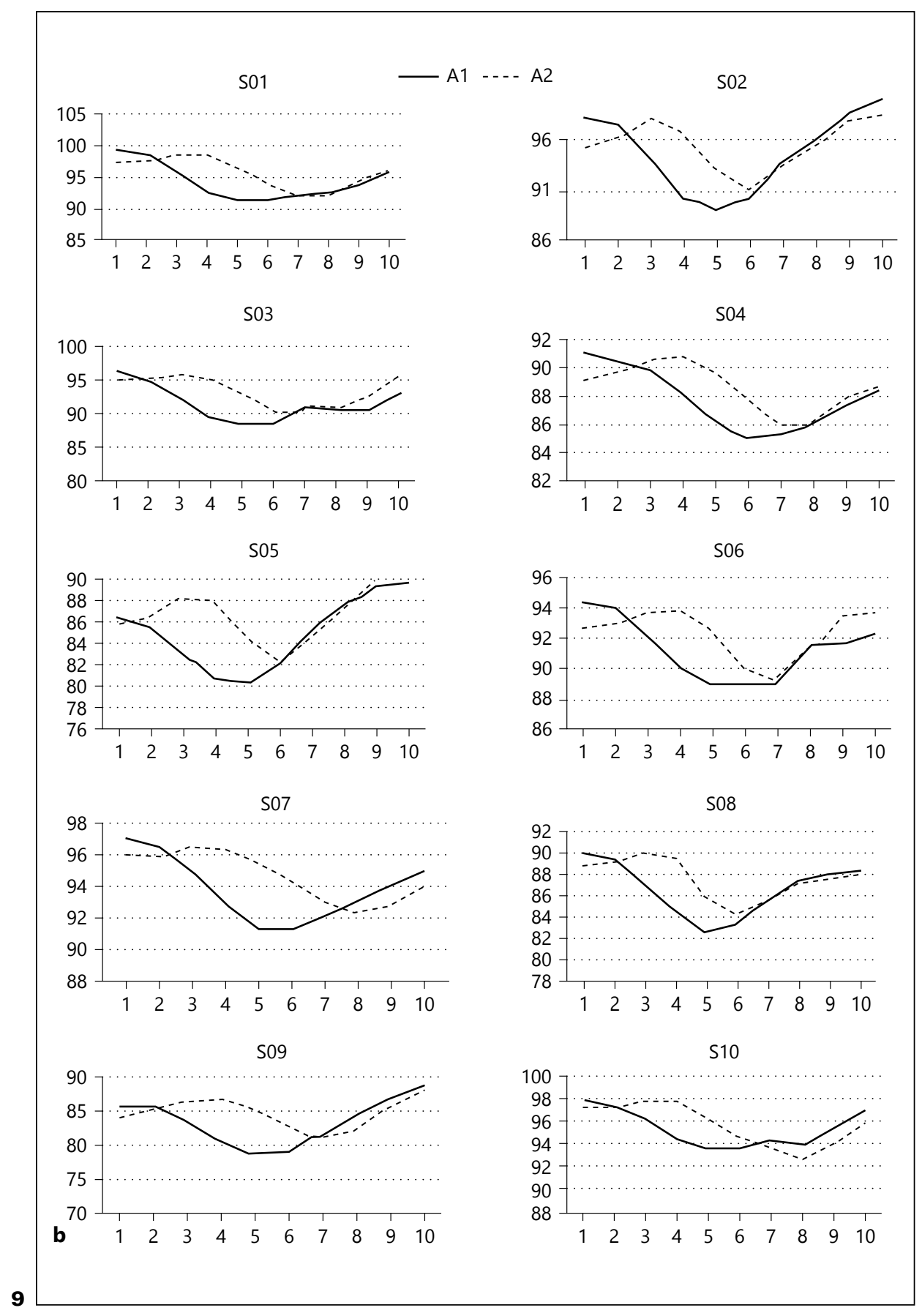


Table 2. Statistical results for accent and focus

\begin{tabular}{|c|c|c|c|c|}
\hline Measure & Effect & Coeff. & $t$ value & $p$ value \\
\hline $\mathrm{F}_{0} \operatorname{maximum}(\mathrm{st})$ & $\begin{array}{l}\text { Accent } \\
\text { Focus } \\
\text { Interaction }\end{array}$ & $\begin{array}{c}-0.05 \\
0.23 \\
0.24\end{array}$ & $\begin{array}{r}-0.2 \\
2.1 \\
1.6\end{array}$ & $\begin{array}{c}0.88 \\
<0.05^{*} \\
0.12\end{array}$ \\
\hline $\mathrm{F}_{0}$ minimum (st) & $\begin{array}{l}\text { Accent } \\
\text { Focus } \\
\text { Interaction }\end{array}$ & $\begin{array}{c}1.2 \\
-0.35 \\
0.25\end{array}$ & $\begin{array}{c}6 \\
-3.1 \\
1.5\end{array}$ & $\begin{array}{c}<0.01 * \\
<0.01 * \\
0.0134\end{array}$ \\
\hline $\mathrm{F}_{0}$ max. alignment & $\begin{array}{l}\text { Accent } \\
\text { Focus } \\
\text { Interaction }\end{array}$ & $\begin{array}{l}0.12 \\
0.01 \\
0.07\end{array}$ & $\begin{array}{l}4.2 \\
0.95 \\
3.9\end{array}$ & $\begin{array}{c}<0.01 * \\
0.34 \\
<0.001 *\end{array}$ \\
\hline $\mathrm{F}_{0}$ min. alignment & $\begin{array}{l}\text { Accent } \\
\text { Focus } \\
\text { Interaction }\end{array}$ & $\begin{array}{r}0.39 \\
0.02 \\
-0.04\end{array}$ & $\begin{array}{c}7.1 \\
1.4 \\
-1.88\end{array}$ & $\begin{array}{c}<0.001 * \\
0.174 \\
0.06\end{array}$ \\
\hline $\mathrm{F}_{0}$ turning point & $\begin{array}{l}\text { Accent } \\
\text { Focus } \\
\text { Interaction }\end{array}$ & $\begin{array}{c}0.44 \\
-0.01 \\
0.016\end{array}$ & $\begin{array}{c}6.5 \\
-1 \\
0.96\end{array}$ & $\begin{array}{l}0.001 * \\
0.306 \\
0.337\end{array}$ \\
\hline Slope of the rise & $\begin{array}{l}\text { Accent } \\
\text { Focus } \\
\text { Interaction }\end{array}$ & $\begin{array}{c}-0.003 \\
0.0003 \\
-0.002\end{array}$ & $\begin{array}{r}-1.7 \\
0.3 \\
-1.2\end{array}$ & $\begin{array}{l}0.14 \\
0.782 \\
0.224\end{array}$ \\
\hline Slope of the fall & $\begin{array}{l}\text { Accent } \\
\text { Focus } \\
\text { Interaction }\end{array}$ & $\begin{array}{l}0.01 \\
0.0006 \\
-0.006\end{array}$ & $\begin{array}{c}7 \\
0.7 \\
-4.1\end{array}$ & $\begin{array}{l}<0.001 * \\
0.5 \\
<0.001 *\end{array}$ \\
\hline AP H\% height & $\begin{array}{l}\text { Accent } \\
\text { Focus } \\
\text { Interaction }\end{array}$ & $\begin{array}{c}0.11 \\
1.8 \\
-0.2\end{array}$ & $\begin{array}{r}0.5 \\
10.3 \\
-0.9\end{array}$ & $\begin{array}{c}0.624 \\
<0.001 * \\
0.385\end{array}$ \\
\hline AP $\mathrm{H} \%$ timing & $\begin{array}{l}\text { Accent } \\
\text { Focus } \\
\text { Interaction }\end{array}$ & $\begin{array}{r}1.1 \\
12.8 \\
-2.4\end{array}$ & $\begin{array}{r}0.6 \\
5.4 \\
-0.7\end{array}$ & $\begin{array}{c}0.565 \\
<0.001^{*} \\
0.467\end{array}$ \\
\hline Boundary slope & $\begin{array}{l}\text { Accent } \\
\text { Focus } \\
\text { Interaction }\end{array}$ & $\begin{array}{c}0.005 \\
0.02 \\
-0.007\end{array}$ & $\begin{array}{r}3.4 \\
10.8 \\
-3.3\end{array}$ & $\begin{array}{l}<0.001 * \\
<0.001 * \\
<0.001 *\end{array}$ \\
\hline Stressed vowel duration, ms & $\begin{array}{l}\text { Accent } \\
\text { Focus } \\
\text { Interaction }\end{array}$ & $\begin{array}{c}6.2 \\
17.2 \\
4\end{array}$ & $\begin{array}{l}0.5 \\
5.1 \\
0.7\end{array}$ & $\begin{array}{c}0.67 \\
<0.001 * \\
0.48\end{array}$ \\
\hline Final vowel duration, $\mathrm{ms}$ & $\begin{array}{l}\text { Accent } \\
\text { Focus } \\
\text { Interaction }\end{array}$ & $\begin{array}{r}7.6 \\
16.1 \\
1.9\end{array}$ & $\begin{array}{l}1.4 \\
5.4 \\
0.4\end{array}$ & $\begin{array}{c}0.219 \\
<0.001 * \\
0.657\end{array}$ \\
\hline
\end{tabular}

Statistical results for each measure examining the effect of accent (1 or 2) and focus (noncontrastive or contrastive) and their interaction. Asterisks indicate statistically significant differences. 
Table 3. Magnitude of differences between the accents in broad and narrow focus

\begin{tabular}{lll}
\hline Measure & Broad & Narrow \\
\hline $\mathrm{F}_{0}$ minimum height (st) & 1.3 & 1.14 \\
$\mathrm{~F}_{0}$ max. alignment (relative) & 0.12 & 0.19 \\
$\mathrm{~F}_{0}$ min. alignment (relative) & 0.35 & 0.4 \\
HTP alignment (relative) & 0.41 & 0.46 \\
\hline
\end{tabular}

than accent 1 or the broad focus realization. The interaction refers to whether the 2 variables interact. These interactions were further investigated with pairwise post hoc tests using the lsmeans package in $\mathrm{R}$.

The results showed that accent type had a significant effect on $\mathrm{F}_{0}$ minimum (L) height, alignment of the initial $\mathrm{F}_{0}$ maximum $(\mathrm{H}), \mathrm{F}_{0}$ minimum $(\mathrm{L})$, and of the HTP. Accent type also affected the stressed syllable slope and boundary slope. Focus realization had a significant effect on $\mathrm{F}_{0}$ maximum $(\mathrm{H})$ and minimum $(\mathrm{L})$ height, AP H\% height and alignment and boundary slope. It also had a significant effect on 2 segmental measures, namely the duration of the stressed vowel for phonologically long vowels and of the final (unstressed) vowel.

In broad focus, accent 2 had a later initial H, L and HTP alignment than accent 1. It also had a higher L. Compared to broad focus, in narrow focus, both accents had a higher $\mathrm{H}$, lower L, higher and earlier AP H\% and longer stressed and unstressed vowels.

There was also a significant interaction for $\mathrm{H}$ alignment, stressed syllable slope and boundary slope. The pairwise tests indicated that $\mathrm{H}$ alignment differed between the 2 accents. It was later for accent 2 than accent 1 in broad focus. Only accent 2 had a later alignment in narrow focus as compared to broad focus. For stressed syllable slope, accent 2 had a steeper slope than accent 1 in broad focus. Accent 2 also had a significantly steeper slope of the fall in broad focus than narrow focus, but focus did not affect the slope for accent 1 . In narrow focus, both accents had a steeper boundary slope.

These interactions demonstrated that narrow focus affected some cues to the accent contrast in the same way while some cues were affected differently. Both accents had a wider pitch range, higher and earlier AP H\% tone, steeper boundary slope and longer vowels in narrow focus than in broad focus. However, only accent 2 had a later alignment of $\mathrm{H}$ in narrow focus, while the timing of accent 1 was not affected.

Combined, the results revealed that in narrow focus, accent 2 words had a higher $\mathrm{L}$ and later alignment of $\mathrm{H}, \mathrm{L}$ and HTP compared to accent 1 words. This is the same set of distinctions between the 2 accents that was found in broad focus. However, in narrow focus, accent 2 words no longer had a steeper slope of the fall or boundary slope than accent 1 words. The accents overall then differed from one another in fewer cues in narrow focus than in broad focus. However, examining the "distance" for those measures that were significantly different for the 2 accents in both focus realizations reveals that the magnitude of the difference between the accents is increased in narrow focus for 3 of the 4 measures (Table 3 ). The alignment distinctions are relative to the beginning of the stressed vowel, divided by the $\mathrm{VC}$ duration (the mean for one 
accent was subtracted from the mean for the other accent to calculate the difference). $\mathrm{F}_{0}$ minimum (L) alignment shows that the difference in relative timing between the accents in broad focus was 0.35 , while in narrow focus this difference increased to 0.4 . The timing for accent 2 is later than for accent 1 in both focus realizations, but that difference is larger in narrow focus. The differences between the accents for H and HTP alignment are also slightly enlarged in narrow focus. The only measure where the difference between the 2 accents is not greater in narrow focus is L height. This suggests that even though the number of cues differentiating accent 1 and 2 in narrow focus is reduced compared to broad focus, some of these cues may be modified in a way that exaggerates the contrast.

\subsection{Discussion}

2.3.1 Describing the Accent Contours

The results of the acoustic analyses revealed accent 2 had a higher $\mathrm{L}$, a later $\mathrm{L}, \mathrm{H}$, HTP alignment, and a steeper slope of the fall than accent 1 . These findings are in line with previous work describing the tonal contrast as one of alignment (Fintoft, 1970; Kristoffersen, 2006b).

In order to further substantiate the presence of an initial $\mathrm{H}$ tone in accent 1 (Nilsen, 1992), additional analyses were conducted. The anacrusis, or unstressed sentence-initial syllables ("Det var" in the examples in section 2.1.2), were marked for whenever the $\mathrm{H}$ occurred before word or vowel onset. Unlike accent 2, accent 1 words frequently appeared with an early (before target word onset) $\mathrm{F}_{0}$ maximum. This was found to occur for $64 \%$ of accent 1 words, and $15 \%$ of accent 2 words. Recall that no difference in $\mathrm{H}$ height between the 2 accents was found. The results suggest an analysis where both accents contain an initial $\mathrm{H}$ tonal target, which for accent 1 words often occurs before word onset. The fact that this initial $\mathrm{H}$ often occurred before word onset could explain why some analyses consider accent 1 to be just an L tone. In the current study, unstressed syllables were included before the target word in order to ensure that no preceding AP $\mathrm{H} \%$ tone would occur, meaning that the initial $\mathrm{H}$ we found here has to belong to the lexical accent. Furthermore, if the target word had been sentence initial, there would be no segmental material for the early $\mathrm{H}$ to be realized. It is likely that the $\mathrm{H}$ sometimes occurs before word onset because the L tone for accent 1 is aligned "early," with the end of the stressed syllable, as will be proposed below.

The presence of this initial $\mathrm{H}$ could reflect a phonological $\mathrm{H}$ tone, but it could also be a phonetic device whereby speakers start off at a higher pitch in order to highlight the important $\mathrm{L}$ tone for accent 1 words. However, in the Oslo dialect accent 1 is just $\mathrm{L}$ and has not been described as having any fall to this target (Fintoft, 1970; Kristoffersen, 2006b). This suggests that an initial phonetic high is not necessary to make the L tone perceptually salient. Next, we examine the alignment of the H, L and HTP tones with the segmental string or syllabic boundary to further elucidate the nature of this initial H (Schepman et al., 2006; Remijsen, 2013). Alignment of the tonal targets can provide insight into which tones characterize the contour of each accent by being closely aligned with a segment or syllable boundary. Table 4 shows the distance in milliseconds of the $\mathrm{F}_{0}$ landmarks $(\mathrm{H}, \mathrm{L}, \mathrm{HTP})$ from the stressed vowel onset and syllable offset (end of the vowel for long vowels and halfway through the total duration of the geminate consonant for short vowels), for each accent. Vowel onset was chosen instead of syllable onset because some words had a simple onset and some had a 
Table 4. Distance (ms) of $F_{0}$ landmarks from vowel onset and syllable offset

\begin{tabular}{|c|c|c|c|c|c|c|}
\hline & \multicolumn{3}{|c|}{ Accent 1} & \multicolumn{3}{|c|}{ Accent 2} \\
\hline & $\mathrm{H}$ & $\mathrm{L}$ & НTP & $\mathrm{H}$ & $\mathrm{L}$ & HTP \\
\hline Vowel onset & -29 & 159 & 16 & 18 & 232 & 106 \\
\hline Syllable offset & -194 & -6 & -149 & -135 & 79 & -49 \\
\hline
\end{tabular}

Negative numbers mean the $\mathrm{F}_{0}$ landmark occurs before the relevant segmental boundary.

complex onset. The alignment shows that the initial $\mathrm{H}$ tone in accent 1 words occurred on average $29 \mathrm{~ms}$ before vowel onset and the HTP $16 \mathrm{~ms}$ after vowel onset, after which $\mathrm{F}_{0}$ falls toward the $\mathrm{L}$ target. This results in the stressed vowel carrying an $\mathrm{F}_{0}$ fall across it. Accent 2, in contrast, had its $\mathrm{H}$ tone on average $18 \mathrm{~ms}$ into the vowel, and its HTP $106 \mathrm{~ms}$ after vowel onset, resulting in a high plateau across much of the vowel. These alignment data provide evidence that both accents have an initial $\mathrm{H}$ tonal target, with significantly different alignment. It was posited that accent 1 in this dialect has an HL contour, as suggested by Kristoffersen (2006b). The analyses here support the presence of an initial $\mathrm{H}$ tone in accent 1 . The differences between the accents lie in the alignment of the HL contour, rather than in the height of the $\mathrm{H}$ or the initial rise to this target. If accent 1 did not have an initial $\mathrm{H}$ tone, it is likely that it would have a shallower initial rise, or no rise, and a lower $\mathrm{H}$ than accent 2 . The absence of the difference in the slope of the rise between the two accents was also confirmed using intonation modeling (Kelly and Schweitzer, 2015).

Examining the distances of the $\mathrm{F}_{0}$ landmarks from segment boundaries further, it can be seen that for accent 1 words, the L tone is aligned closely with the end of the syllable (preceding it by only $6 \mathrm{~ms}$ ). For accent 2 , the $\mathrm{H}$ tone is most closely aligned with vowel onset (only $18 \mathrm{~ms}$ after it). This suggests that accent 1 is right-aligned and accent 2 is left-aligned (Schepman et al., 2006; Remijsen, 2013). For accent 1, the HTP being only $16 \mathrm{~ms}$ after vowel onset is likely due to the alignment of the $\mathrm{L}$ with the end of the syllable. That is, in order to accommodate the L target's alignment with the edge of the accented syllable, $\mathrm{F}_{0}$ starts to lower earlier from the preceding $\mathrm{H}$ compared to accent 2 words. This is in line with results in Fintoft (1970) where the L tone was found to be at vowel offset in V:C words and halfway into the geminate consonant in VC: words. The current results indicate that accent 1 is characterized by an $\mathrm{F}_{0}$ fall and accent 2 by the early alignment of the initial $\mathrm{H}$.

Combined, these results suggest that accent 1 is phonologically characterized by an $\mathrm{HL}$ contour with an initial $\mathrm{H}$ and then an $\mathrm{L}$ tone that is associated with the right edge of the syllable $\left(\mathrm{H}+\mathrm{L}^{*}\right.$ within the intonational phonology framework proposed by Pierrehumbert, (1980)) while accent 2 is characterized by an HL contour with an $\mathrm{H}$ tone associated with the left edge of the syllable and a trailing $\mathrm{L}$ tone $\left(\mathrm{H}^{*}+\mathrm{L}\right)$. Work by Prieto et al. (2005), Morén and Zsiga (2006), and Remijsen (2013) shows analyses of languages (with and without lexical tone) where a tone can be linked with either edge of the tone-bearing unit, thus distinguishing the same tonal sequence through alignment differences. Kristoffersen (2000) interprets similar results for East Norwegian as the $\mathrm{L}$ tone in accent 1 , and the $\mathrm{H}$ tone in accent 2, linking with the 


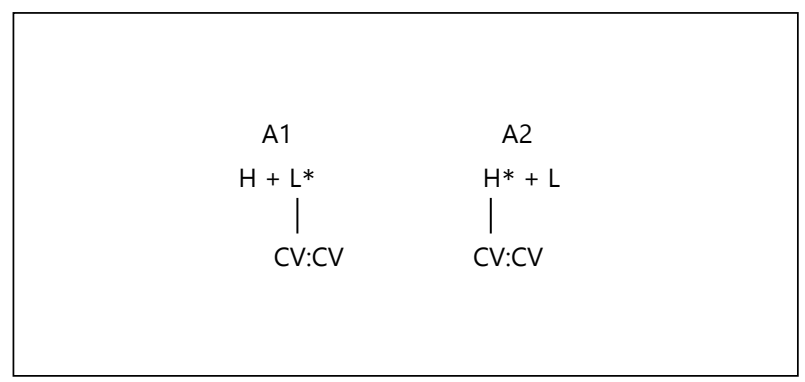

Fig. 10. Phonological analysis of the Trøndersk disyllabic accents.

stressed syllable. Analyses where the tones associate with the stressed syllable are also given for Stockholm Swedish by Gussenhoven and Bruce (1999) and for Swedish and Norwegian by Riad (1998). The results here also coincide with those found for Oppdal and Trondheim, where the L tone was described as being associated with the stressed syllable in accent 1 and the poststressed syllable in accent 2 (Fintoft, 1970; Kristoffersen, 2003, 2006b). For the Trøndersk dialect, the phonological association with the accented syllable as indicated by acoustic analyses is provided in Figure 10. Another alternative, as proposed by Kristoffersen (2006a) for the North Gudbrandsdal dialect (spoken south of the Trøndelag region), is that the initial $\mathrm{H}$ in accent 1 is actually an independent tonal target associated with the syllable preceding the stressed syllable. Recall that for $64 \%$ of accent 1 words, the $H$ occurred before vowel onset. If this prestress syllable analysis were to hold, though, it is likely that for all accent 1 target words, the initial H should occur before word onset, which was not confirmed by the acoustic analyses.

Segmental makeup and syllable type can further shift tonal alignment. For example, Schepman et al. (2006) found an earlier alignment of the $\mathrm{H}$ tone in long vowels than in short vowels in Dutch. In the current study, the $\mathrm{C}$ is the onset of the final syllable in $\mathrm{V}: \mathrm{C}$ words. In the case of $\mathrm{VC}$ :, the second part of the geminate consonant is the onset of the final syllable. The average length of the vowel and consonant is $240 \mathrm{~ms}$, while a long vowel alone is $160 \mathrm{~ms}$ and a short vowel $80 \mathrm{~ms}$. Accent 1 words have their L aligned $150 \mathrm{~ms}$ into the accented syllable, which is at vowel offset in V:C words and about halfway through the consonant in VC: words. Accent 2 words have their $\mathrm{H}$ aligned $18 \mathrm{~ms}$ into the vowel, HTP $106 \mathrm{~ms}$ after vowel onset, and their L is aligned $230 \mathrm{~ms}$ after vowel onset, which is into the second syllable. The syllable makeup thus determines the alignment of the tonal accents in Trøndersk, with the L tone in accent 1 words occurring at the end of the vowel in words with a phonologically long vowel and in the following consonant in words with a short vowel. In contrast with the current findings, Fintoft (1970) described accent 2 as having a longer final vowel than accent 1 . This difference may be due to all target words in the Fintoft study being sentence final which was avoided here. In the current experiment, furthermore, both the accent contrast and its interaction with focus are examined, which may have resulted in larger variability of vowel durations. When a subset of the current data was analyzed to examine the accent contrast in broad focus only, accent 2 was found to have a longer final vowel than accent 1 (Kelly and Smiljanić, 2014). However, this difference was no longer significant in the current, larger data set. 


\subsubsection{The Accent Contrast in Narrow Focus}

In narrow focus both accents had a wider pitch range, higher and earlier AP $\mathrm{H} \%$ tone, steeper boundary slope and longer vowels. Accent 2 also had later $\mathrm{H}$ alignment compared to broad focus.

The higher and earlier AP $\mathrm{H} \%$ in narrow focus is in line with previous findings for Norwegian (Koreman et al., 2009; Mixdorff et al., 2010). The higher AP H\% tone likely arises from the combined $\mathrm{H}$ targets for the boundary and focal tones (Fretheim, 1987b; Nilsen, 1989; Kristoffersen, 2000). The steeper boundary slope is a result of this change in height and alignment of the boundary tone in narrow focus. The results also revealed that both accents had an expanded pitch range, higher $\mathrm{H}$ and lower $\mathrm{L}$ tones, on the narrow focus words. This is in line with findings on narrow focus across a number of typologically diverse languages (e.g., Xu, 1999; Scholz, 2012; Peters et al., 2014). The current study also found that narrow focus affected segmental durations. In narrow focus, phonologically long vowels were lengthened but short vowels were not. Such asymmetrical lengthening was found in a number of other languages, such as Swedish (Bruce, 1977; Bannert, 1979) and Serbian and Croatian (Smiljanić, 2006). Final unstressed vowels were also lengthened in narrow focus as was found for Swedish (Heldner and Strangert, 2001). The lengthening patterns suggest that narrow focus impacts the whole target word, not just the stressed syllable. Furthermore, the asymmetrical impact of focus on phonologically short and long vowels enhances the distinction between them.

The results also revealed an asymmetrical effect of narrow focus on the pitch contours of the two accents. The alignment of the tonal targets for the two accents could have been affected by narrow focus in ways that would result in the maintenance or diminishing of the contrast. We hypothesized that accent 1 would have an earlier alignment and accent 2 a later alignment in narrow focus. However, accent 2 words had a later alignment of the $\mathrm{F}_{0}$ maximum in narrow focus compared to broad focus while the alignment of the tones in accent 1 words did not change. This suggests that, similar to the vowel length differences, the alignment is modified in a way that it enlarges the difference between the accents in narrow focus. These results further provide evidence that the presence of the lexical tonal accent contrast limits how the pitch cues are used to express pragmatic focus. Accent 1 words, therefore, express narrow focus by expanding vertically, rather than changing alignment.

Finally, Table 4 showed that although the accents differed from one another in fewer cues in narrow focus than in broad focus, the magnitude of these differences was increased in narrow focus. These results, however, have to be taken with caution. Even though an increase in differences between accent 1 and accent 2 for some of these cues is noted, their magnitude is rather small. Whether this difference is sufficient to affect listeners' perception of the contrast needs to be examined through perception experiments.

\section{Experiment 2: Accent Realization in AP-Final Position}

\subsection{Methods}

Participants, procedure and measurements were identical to experiment 1 . The recordings for both experiments were made in the same sitting for each participant. The sentences for all of the different conditions (broad focus, narrow focus, AP-final) were interspersed. 


\subsubsection{Materials}

The sentences had a similar structure to the broad focus sentences, except that for the AP-final condition, the target word occurred at the right edge of the AP (there were no unstressed syllables following the target word). The word immediately following the target word was focused, to ensure that a new AP began at this point and also that the target word was not focused.

Accent 1, AP-medial:

Det var glimtet $\mathrm{i}$ en film, men ikke i et stykke.

$\left(\left(\left(\text { Det var }\left({ }^{1} \text { glimtet-i-en }\right)_{\mathrm{AP}}\left({ }^{1} \mathrm{FILM}\right)_{\mathrm{AP}}\right)_{\mathrm{IP}} \text {, men itj i et }\left({ }^{2} \mathrm{STYKKE}\right)_{\mathrm{AP}}\right)_{\mathrm{IP}}\right)_{\mathrm{IU}}$

"There was the flash in a film, but not in a play."

Accent 1, AP-final:

Det var glimtet før, men ikke nå.

$\left(\left(\left(\text { Det var }\left({ }^{1} \text { glimtet }\right)_{\mathrm{AP}}(\mathrm{F} \varnothing \mathrm{R})_{\mathrm{AP}}\right)_{\mathrm{IP}} \text {, men itj }(\mathrm{N} \AA)_{\mathrm{AP}}\right)_{\mathrm{IP}}\right)_{\mathrm{IU}}$

"There was the flash before, but not now."

Accent 2, AP-medial:

Det var et minne $\mathrm{i}$ en film, men ikke i et stykke.

$\left(\left(\left(\text { Det var et }\left({ }^{2} \text { minne-i-en }\right)_{\mathrm{AP}}\left({ }^{1} \mathrm{FILM}\right)_{\mathrm{AP}}\right)_{\mathrm{IP}} \text {, men itj i et }\left({ }^{2} \mathrm{STYKKE}\right)_{\mathrm{AP}}\right)_{\mathrm{IP}}\right)_{\mathrm{IU}}$

"There was a memory in a film, but not in a play."

Accent 2, AP-final:

Det var et minne før, men ikke nå.

$\left(\left(\left(\text { Det var et }\left({ }^{2} \text { minne }\right)_{\mathrm{AP}}(\mathrm{F} \varnothing \mathrm{R})_{\mathrm{AP}}\right)_{\mathrm{IP}} \text {, men itj }(\mathrm{N} \AA)_{\mathrm{AP}}\right)_{\mathrm{IP}}\right)_{\mathrm{IU}}$

"There was a memory before, but not now."

\subsubsection{Measurements and Analysis}

The measurements and analysis were identical to experiment 1: stressed vowel and consonant duration, unstressed vowel duration, height and alignment of $\mathrm{H}$ and $\mathrm{L}$, HTP alignment, slope of the rise, slope of the fall, boundary slope from L to AP H\%, and the height and alignment of the AP $\mathrm{H} \%$. Note that for words in AP-final position, the AP $\mathrm{H} \%$ tone occurred on the target word rather than 2 syllables after it. It was predicted that in AP-final position, the lexical tones would occur earlier due to tonal crowding by the earlier AP tone. Furthermore, it was predicted that this might also result in the $\mathrm{L}$ tone being higher in this condition.

\subsection{Results}

Average results can be found in Appendix D (Tables 19-30). Figure 11a shows the full AP (in this case, just the target word) for accent 1 words in AP-final position, and Figure $11 \mathrm{~b}$ shows accent 2 in AP-final position. (AP-medial position is the same as in Fig. 7a, b.)

From the figures, it can be seen that the 2 accents are distinct from each other in both positions, but some differences are also noted.

Figure 12 shows both accents in AP-final position for each speaker. Table 5 shows the significant results for the mixed model linear regression. In this case, accent and position were the independent variables. Accent refers to the differences between the 2 accents. Position refers to the difference between the AP-medial and AP-final productions. The reference level is the AP-medial production. 


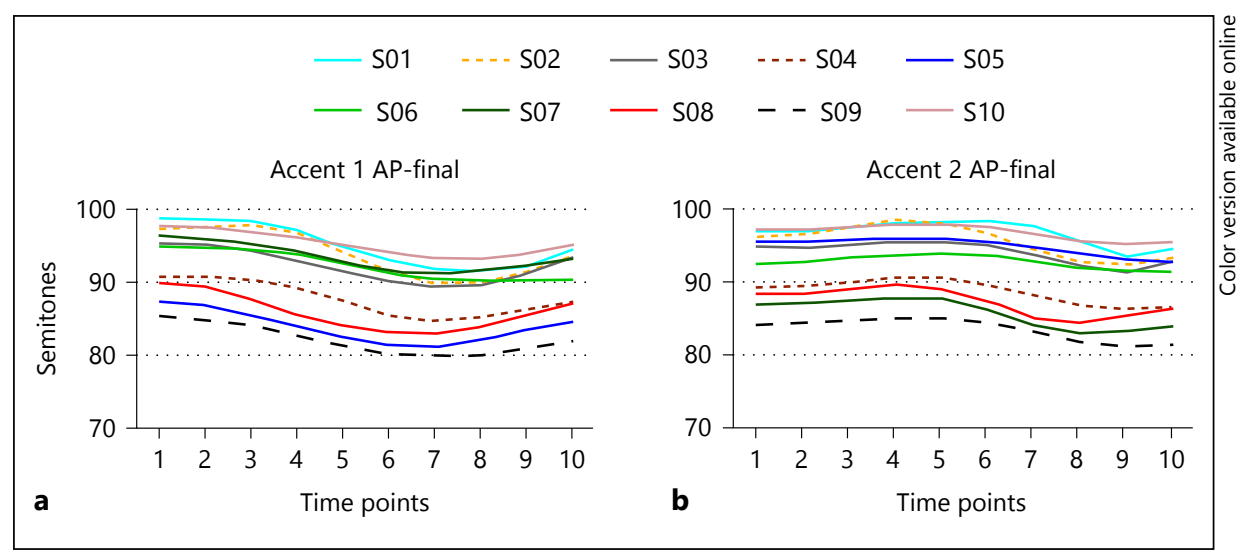

Fig. 11. a Contours of accent 1 words in AP-final position for each speaker. The $x$-axis indicates semitones, the $y$-axis time points. b Contours of accent 2 words in AP-final position for each speaker. The $x$-axis indicates semitones, the $y$-axis time points.

As expected, the cues that differentiate the 2 accents are consistent with the previous experiment. In AP-medial position, the L tone was aligned later and was higher for accent 2 compared to accent 1 . Regarding the effect of AP-level intonation on accent realization, the main effects show that the accents in AP-final position had a lower and later AP H\% tone, shorter stressed vowel (when phonologically long), and shorter consonant duration (when phonologically short). Both accents also had a higher L, steeper boundary slope and longer final vowel in AP-final position. Accent 2 had an earlier H and $\mathrm{L}$ alignment in AP-final position compared to AP-medial position.

\subsection{Discussion}

When the target word was in AP-final position, the intonation-level AP $\mathrm{H} \%$ tone was lower in height, and it was aligned later in the phrase (closer to the end of the AP). The lower and later AP H\% and the steeper boundary slope can be attributed to the fewer syllables available to reach the AP $\mathrm{H} \%$ in this condition compared to the AP-medial position in which 2 syllables followed the target word. A similar result was found by Gårding (1993) for West Swedish. That study examined the effect of focus tones on lexical tones. The results revealed that increasing the number of unstressed syllables between the final lexical $\mathrm{L}$ tone and the phrase-final $\mathrm{H}$ focus tone made the contour between these 2 points shallower, similar to what was found here for the AP tones. The later AP H\% tone here, then, is likely caused by tonal crowding, that is, the lexical tones push it closer to the AP boundary.

With regard to the main question of the impact of sentence-level intonation on the lexical tonal contrast, the results showed that both accents had a higher L in AP-final position. Since the AP is shorter in the AP-final condition, it is likely that there is not enough time to reach as low an $\mathrm{F}_{0}$ as there is in AP-medial position. In AP-medial position, the lexical tones surface on the target word, and the AP tone is realized 2 syllables after the target word. It is likely that in AP-final position there is not enough time to reach the targets, so the $\mathrm{L}$ target is undershot. A similar result was reported for accent 1 in Norwegian in Teig (2001), where a 1-syllable AP had a shallower drop to the L tone 


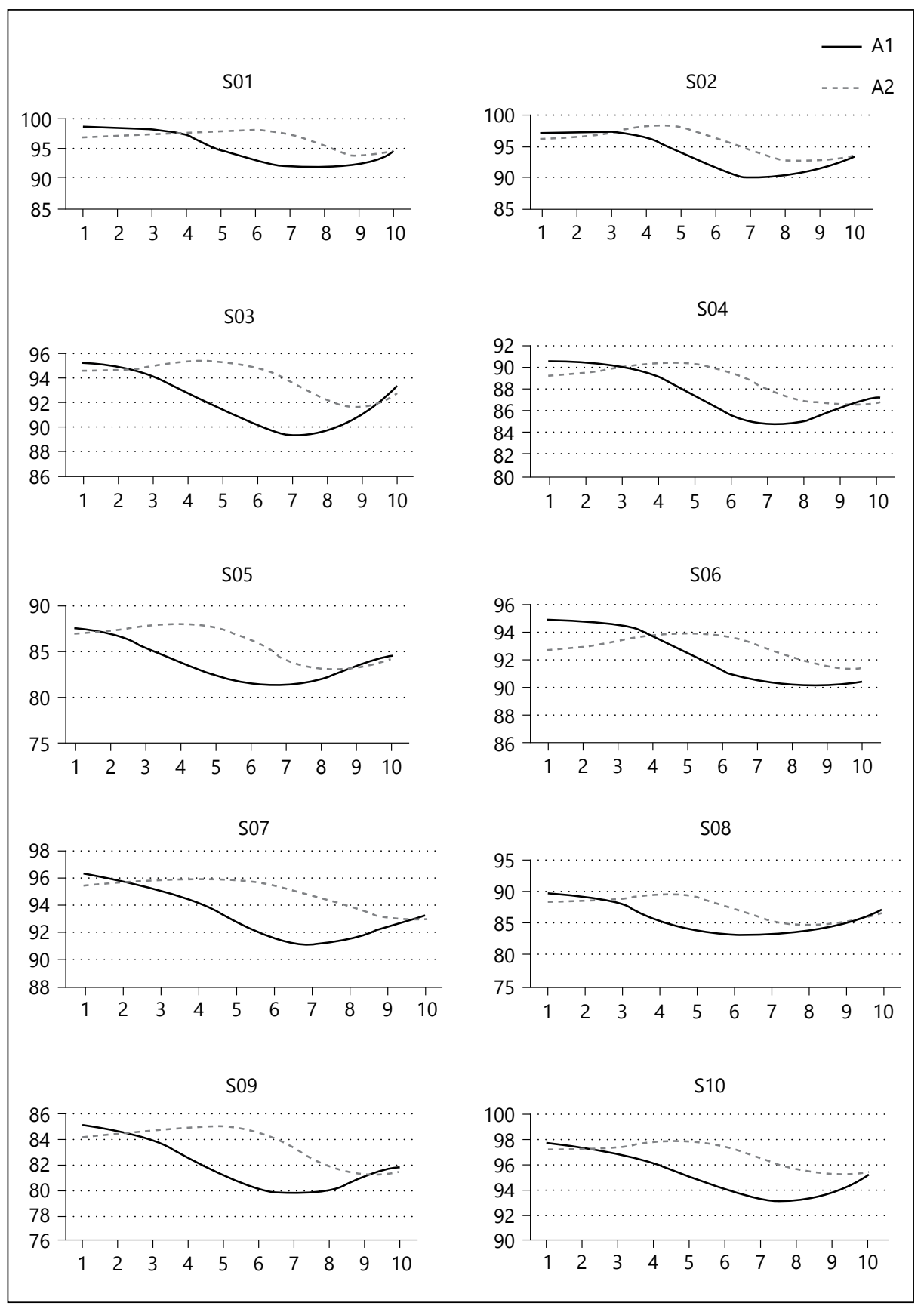

Fig. 12. Accent 1 and accent 2 in AP-final position by speaker. The $x$-axis indicates semitones, the $y$-axis time points. 
Table 5. Statistical results for accent and position

\begin{tabular}{|c|c|c|c|c|}
\hline Measure & Effect & Coeff. & $t$ value & $p$ value \\
\hline $\mathrm{F}_{0} \operatorname{maximum}(\mathrm{st})$ & $\begin{array}{l}\text { Accent } \\
\text { Position } \\
\text { Interaction }\end{array}$ & $\begin{array}{r}-0.04 \\
0.03 \\
-0.17\end{array}$ & $\begin{array}{r}-0.1 \\
0.3 \\
-1.1\end{array}$ & $\begin{array}{l}0.916 \\
0.767 \\
0.261\end{array}$ \\
\hline $\mathrm{F}_{0}$ minimum $(\mathrm{st})$ & $\begin{array}{l}\text { Accent } \\
\text { Position } \\
\text { Interaction }\end{array}$ & $\begin{array}{l}1.2 \\
0.3 \\
0.8\end{array}$ & $\begin{array}{l}5.4 \\
2.6 \\
5.2\end{array}$ & $\begin{array}{c}<0.01 * \\
0.01 * \\
<0.001 *\end{array}$ \\
\hline $\mathrm{F}_{0}$ max. alignment & $\begin{array}{l}\text { Accent } \\
\text { Position } \\
\text { Interaction }\end{array}$ & $\begin{array}{l}0.12 \\
0.1 \\
-0.14\end{array}$ & $\begin{array}{c}10.6 \\
10.4 \\
-10\end{array}$ & $\begin{array}{l}<0.001 * \\
<0.001 * \\
<0.001 *\end{array}$ \\
\hline $\mathrm{F}_{0}$ min. alignment & $\begin{array}{l}\text { Accent } \\
\text { Position } \\
\text { Interaction }\end{array}$ & $\begin{array}{r}0.39 \\
-0.01 \\
-0.06\end{array}$ & $\begin{array}{r}7.3 \\
-1.1 \\
-3.2\end{array}$ & $\begin{array}{c}<0.001 * \\
0.276 \\
0.001 *\end{array}$ \\
\hline $\mathrm{F}_{0}$ turning point & $\begin{array}{l}\text { Accent } \\
\text { Position } \\
\text { Interaction }\end{array}$ & $\begin{array}{l}0.44 \\
0.003 \\
0.01\end{array}$ & $\begin{array}{l}5.6 \\
0.2 \\
0.7\end{array}$ & $\begin{array}{r}<0.01 * \\
0.817 \\
0.463\end{array}$ \\
\hline Slope of the rise & $\begin{array}{l}\text { Accent } \\
\text { Position } \\
\text { Interaction }\end{array}$ & $\begin{array}{c}-0.003 \\
0.0001 \\
0.001\end{array}$ & $\begin{array}{c}-1.7 \\
0.2 \\
1\end{array}$ & $\begin{array}{l}0.14 \\
0.88 \\
0.339\end{array}$ \\
\hline Slope of the fall & $\begin{array}{l}\text { Accent } \\
\text { Position } \\
\text { Interaction }\end{array}$ & $\begin{array}{r}0.009 \\
-0.002 \\
0.004\end{array}$ & $\begin{array}{r}6.1 \\
-2.2 \\
3.2\end{array}$ & $\begin{array}{l}<0.05^{*} \\
<0.001^{*} \\
<0.01^{*}\end{array}$ \\
\hline AP H\% height & $\begin{array}{l}\text { Accent } \\
\text { Position } \\
\text { Interaction }\end{array}$ & $\begin{array}{r}0.1 \\
-1.2 \\
-0.2\end{array}$ & $\begin{array}{r}0.6 \\
-8.6 \\
-0.9\end{array}$ & $\begin{array}{c}0.585 \\
<0.001 * \\
0.356\end{array}$ \\
\hline AP $\mathrm{H} \%$ timing & $\begin{array}{l}\text { Accent } \\
\text { Position } \\
\text { Interaction }\end{array}$ & $\begin{array}{r}1.2 \\
-4.3 \\
-9.3\end{array}$ & $\begin{array}{r}0.7 \\
-2.5 \\
-3.6\end{array}$ & $\begin{array}{c}0.511 \\
<0.05^{*} \\
<0.001 *\end{array}$ \\
\hline Boundary slope & $\begin{array}{l}\text { Accent } \\
\text { Position } \\
\text { Interaction }\end{array}$ & $\begin{array}{l}0.005 \\
0.02 \\
-0.01\end{array}$ & $\begin{array}{r}3.3 \\
14.1 \\
-4.7\end{array}$ & $\begin{array}{l}<0.001 * \\
<0.001 * \\
<0.001 *\end{array}$ \\
\hline Stressed vowel duration, $\mathrm{ms}$ & $\begin{array}{l}\text { Accent } \\
\text { Position } \\
\text { Interaction }\end{array}$ & $\begin{array}{l}\quad 6.1 \\
-16.6 \\
-7.6\end{array}$ & $\begin{array}{r}0.4 \\
-5.4 \\
-1.5\end{array}$ & $\begin{array}{c}0.688 \\
<0.001 * \\
0.13\end{array}$ \\
\hline Final vowel duration, ms & $\begin{array}{l}\text { Accent } \\
\text { Position } \\
\text { Interaction }\end{array}$ & $\begin{array}{l}7.5 \\
8.5 \\
3.1\end{array}$ & $\begin{array}{l}1.8 \\
3.2 \\
0.8\end{array}$ & $\begin{array}{c}0.127 \\
<0.001 * \\
0.397\end{array}$ \\
\hline
\end{tabular}

Statistical results for each measure examining the effect of accent (1 or 2) and position (AP-medial or AP-final) and their interaction. Asterisks indicate statistically significant differences.

$\begin{array}{llll} & \begin{array}{l}\text { Phonetica 2017;74:193-230 } \\ \text { DOI: } 10.1159 / 000453270\end{array} & \text { Kelly/Smiljanić } \\ & \end{array}$


than a 2-syllable AP. The results of the current study also revealed that accent 2 words had an earlier $\mathrm{H}$ and L alignment in AP-final position. This fits with the results for the $\mathrm{L}$ height and the lower and later AP $\mathrm{H} \%$, in that the reduced segmental material leads to undershooting of the targets as well as compression of the contour. Compression refers to the entire tonal contour being realized on a smaller amount of segmental material, rather than the deletion of some of the tonal targets (Bannert and Bredvad-Jensen, 1975, 1977; Grabe et al., 2000). The compressing of the contour in the AP-final condition likely causes the L to be higher in both accents, and $\mathrm{H}$ and $\mathrm{L}$ to be aligned earlier in accent 2 . Research on other languages has provided evidence of boundary tones affecting the alignment of pitch accent tonal targets, for example in English (Silverman and Pierrehumbert, 1990; Pierrehumbert, 2000), Spanish (Prieto et al., 1995) and Greek (Arvaniti et al., 2006). The reason that this only changes for accent 2 words is related to the fact that accent 1 words already have earlier tonal alignment. Since accent 2 has a later alignment than accent 1, its lexical tones are closer to the AP boundary, so they are more likely to be affected than the tones in accent 1 .

The overall effect of AP-final position on segments was that both accents had a shorter stressed vowel whenever that vowel was phonologically long, and a longer final (unstressed) vowel in the target word. The longer final vowel duration reflects phrasefinal lengthening (Beckman and Pierrehumbert, 1986; Beckman and Edwards, 1990; Gussenhoven and Bruce, 1999). The lengthening pattern suggests that the domain of phrase-final lengthening is the boundary-adjacent vowel, since no other segments in the word were lengthened. The stressed vowel in the target word was shortened in AP-final position, but only for phonologically long vowels. In such words, the consonants are phonologically short. These short consonants also get shortened in AP-final position. In VC: words with a short vowel, neither the vowel nor the consonant were affected. Since the medial geminate consonant in C[VC.C]V words is ambisyllabic, the part of it in the stressed syllable is not considered long, so this might explain why it does not shorten either. It is unclear why the stressed vowel would shorten in AP-final position. Compensatory shortening of the stressed syllable is an unsatisfactory explanation since the shortening only occurs in words with a long vowel, and not those with a long consonant. The segmental results revealed that syllable structure did not affect phrase-final lengthening, but it did affect lengthening and shortening patterns in the stressed syllable itself. Only words with V:C syllables underwent shortening in AP-final position. Since these are the same words that underwent vowel lengthening in narrow focus, a limitation on the amount of lengthening (long vowel in phrase final position) also seems an unlikely account for these lengthening differences. This needs to be explored further in future studies.

In summary, the results revealed that phrase-level intonation had minimal acoustic impact on the lexical tones of accent 1 , but affected the alignment of tones in accent 2 . Comparing the results of this experiment with the previous one, it was found that narrow focus affected the phonetic realization of the accents more than phrase-level intonation. In particular, tonal alignment for accent 2 became later in narrow focus, but alignment of accent 1 was unchanged, leading to a greater difference between the accents. It was argued above that through such changes narrow focus made the accents acoustically more different from one another, that is, the lexical tonal contrast was exaggerated. The effect of position in the AP actually made the $\mathrm{H}$ and $\mathrm{L}$ alignment earlier in accent 2 in AP-final position compared to AP-medial position. For this accent, the lexical tones moved away from the AP boundary and closer to where the tones lie in an accent 1 word. A smaller 
difference between the 2 accents in this measure in AP-final position was found. This indicates that the contrast is possibly diminished between the 2 accents in AP-final position. However, a perception test would be necessary to determine whether this impacts identification of the accents. Accent 2 retains its later alignment of the HTP than accent 1 , which could provide sufficient cues to differentiate the 2 accents. Overall, the results of this study demonstrated that even though sentential intonation and pragmatic focus both impact $\mathrm{F}_{0}$ and segmental properties, the effect is qualitatively different.

\section{General Discussion}

This study examined how the lexical tonal accent contrast is realized in the Trøndersk variety of East Norwegian and how it is affected by pragmatic focus and phrasal intonation. The accent contrast was found to be one of timing. Accent 1 had an $\mathrm{L}$ tone aligned with the end of the accented syllable, and accent 2 an $\mathrm{H}$ tone aligned with the beginning of the accented syllable. Furthermore, acoustic analyses revealed that many accent 1 words had an $F_{0}$ peak aligned prior to word onset. This led us to posit that both accents have an HL contour with accent 2 having a later timing of the $\mathrm{F}_{0}$ landmarks in relation to the segmental string. Accent 2 words were also found to have a higher $\mathrm{L}$ than accent 1 words, but no difference between the 2 accents was found for $\mathrm{H}$ height, which was taken as further support for the HL tonal targets for both accents. In phonological terms, accent 1 was described as HL with the L associated with the initial, stressed syllable, and the preceding $\mathrm{H}$ timed with respect to this $\left(\mathrm{H}+\mathrm{L}^{*}\right)$. Accent 2 was described as HL with the initial $\mathrm{H}$ associated with the initial, stressed syllable and the trailing $\mathrm{L}$ tone surfacing on the following, unstressed syllable $\left(\mathrm{H}^{*}+\mathrm{L}\right)$. The 2 accent types are thus distinguished by a presence of a fall versus a high $\mathrm{F}_{0}$ plateau over the accented vowel. The presence of the initial fall may be a salient perceptual cue for the accent differentiation. This was further examined and confirmed with perception tests with manipulated contours (Kelly, 2015) which showed that an early fall is necessary for the perception of accent 1 . As Remijsen and Ayoker (2014) note: "When the $\left[F_{0}\right]$ drop is aligned early in or at the center of the vowel... then the result is a falling $\mathrm{F}_{0}$ contour over the vowel, the part of the syllable with greatest intensity, so that the falling contour is likely to be perceptually salient in some way" (p. 1). In this context, the early fall in accent 1 is likely to be salient to listeners, which allows them to distinguish it from accent 2 . It is posited that it is the presence of the early $\mathrm{H}$ tone as part of the phonological tonal makeup in accent 1 that allows the initial fall to occur. Therefore, both production and perception indicated that the identifying characteristic of accent 1 is an initial fall (correlated with a right-aligned low tone) and of accent 2 an initial high tone and $\mathrm{F}_{0}$ plateau. These results demonstrate that the contrast in the Trøndersk dialect is one of alignment rather than a tonal makeup difference between the accents, in line with analyses by Fintoft (1970) for Trondheim and Kristoffersen (2006b) for Oppdal. The current results are particularly similar to Fintoft's (1970) findings for the Trondheim variety, which he described in terms of accent 1 having an L tone in the stressed vowel and accent 2 having an $H$ tone across most of the stressed vowel before it begins to fall. This also means that this dialect is more different from the Oslo variety (accent $1 \mathrm{~L}$ and accent $2 \mathrm{HL}$ ) - even though both varieties are considered East Norwegian - and also different from other Norwegian dialects where accent 1 is described as having only either a low tone or a high tone, and the difference between 
the 2 accents is in tonal makeup rather than timing. Interestingly, the current results are reminiscent of the results for Stockholm Swedish, described by Bruce (1977) as having a contrast where both accents are HL and accent 2 is aligned later than accent 1.

Both accents were shown to have a wider pitch range in narrow focus, but accent 2 also has a later timing compared to broad focus. The accents were thus affected differently by focus. Even though cues that distinguish the accents in broad focus were also used to distinguish them in narrow focus, the magnitude of the difference between them was bigger in narrow focus. We argued that the contrast was overall enlarged. This exaggeration could lead to more accurate accent discrimination which needs to be confirmed with perception experiments. Phonologically long vowels were also lengthened under narrow focus, while short vowels were not. Similar to the impact of focus on the $\mathrm{F}_{0}$ contour, this asymmetrical lengthening results in an exaggeration of the phonological vowel length contrast. This effect was not shown for consonants. As mentioned, previous work on focus in Norwegian had examined the accent phrase tone rather than the lexical tones. The current study expanded upon previous work by showing how the lexical tones change under focus. Work on Swedish described single-peaked dialects, where the pitch range of the accents expands in focus, and double-peaked dialects, which get an extra $\mathrm{H}$ tone in focus (Bruce, 2005). Trøndersk does not truly follow either of these models, since the 2 accents were affected quite differently by focus. While the effects on segments were the same for both accents, accent 1 had no change in tonal timing but an expansion in pitch range, while accent 2 had a change in timing. These results indicate that focus does not have to exhibit the same effects on both accents, but may be constrained by having to maintain or perhaps even enhance the tonal contrast.

Finally, phrasal intonation affected the lexical $\mathrm{F}_{0}$ contour. The main impact was seen on L height, which was not as low as in AP-medial position. We argued that this was due to tonal crowding since the AP H\% surfaced on the accented word and there was subsequently less time to realize the $\mathrm{L}$ target. The $\mathrm{H}$ and $\mathrm{L}$ were also aligned earlier for accent 2 words in AP-final position. This is likely because of the later timing of accent 2 tones compared to accent 1 tones. This later timing puts accent 2 tonal targets closer to and thus more easily affected by the AP boundary tone. The results also showed that the AP $\mathrm{H} \%$ tone and the boundary slope leading up to it were impacted depending on how much segmental material was available between the accented syllable and the phrase boundary. As mentioned in section 3.3, research on a variety of languages has shown the effect of boundary tones on tonal alignment. For instance, it is known that nuclear pitch accents can have their timing affected by boundary tones due to tonal crowding, where there is not enough time or material to produce all the tones (Silverman and Pierrehumbert, 1990; Arvaniti et al., 2006). This occurs in languages without lexical accents, such as English, and leads to earlier alignment of the tones in a nuclear pitch accent when a boundary tone occurs on the same word (Shue et al., 2008; Ladd et al., 2009). Similarly, the results here also reflect those of Schepman et al. (2006) and Ladd et al. (2009) whereby syllable structure and vowel length affect tonal alignment, which appears to be based around the syllable boundary. In this way, the findings for the tonal accents in Trøndersk relate to findings for languages even without lexical tonal accents. These similarities indicate that regardless of whether a particular tune is lexical or at a phrasal level, the tones behave in similar ways, with constraints based on tonal crowding, syllable structure and compression, among others.

These results shed light on the interaction of focus and phrasal intonation with a lexical tonal contrast. The close examination of the effect of narrow focus and position in the 
utterance revealed that they had opposite effects on the $\mathrm{H}$ and $\mathrm{L}$ timing in accent 2 words and on the tonal contrast realization overall. It was found that syllable structure has an effect on these interactions, indicating the importance of examining duration cues as well as pitch cues, in the context of the syllable. Finally, the phonetic measurements obtained here provided an insight into the possible phonological structure of tonal accent contrasts.

\section{Appendixes}

\subsection{Appendix A: Speaker Details}

Table 1. Speaker details

\begin{tabular}{llll}
\hline Speaker No. & Hometown & Sex & Age range, years \\
\hline 01 & Tingvoll & F & $36-40$ \\
02 & Oppdal & F & $25-30$ \\
03 & Tingvoll & F & $30-35$ \\
04 & Øksendal & M & $18-24$ \\
05 & Rennebu & M & $36-40$ \\
06 & Surnadal & F & $18-24$ \\
07 & Sunndal & F & $18-24$ \\
08 & Halsa & M & $36-40$ \\
09 & Alvundeid & M & $36-40$ \\
10 & Surnadal & F & $18-24$ \\
\hline
\end{tabular}

5.2 Appendix B: Target Words

Table 6. Target words and sentences

\begin{tabular}{|c|c|c|c|c|}
\hline Accent & Target Word & Gloss & Condition & Sentence \\
\hline 1 & limet & the glue & $\begin{array}{l}\text { Broad } \\
\text { Narrow } \\
\text { AP-final }\end{array}$ & $\begin{array}{l}\text { Det var limet i en film, men ikke i et stykke. } \\
\text { There was the glue in a film, but not in a play. } \\
\text { Det var limet i en film, men ikke saks. } \\
\text { There was the glue in a film, but not scissors. } \\
\text { Det var limet før, men ikke nå. } \\
\text { There was the glue before, but not now. }\end{array}$ \\
\hline 1 & linet & the flax/linen & $\begin{array}{l}\text { Broad } \\
\text { Narrow } \\
\text { AP-final }\end{array}$ & $\begin{array}{l}\text { Det var linet } i \text { en film, men ikke i et stykke. } \\
\text { There was the flax in a film, but not in a play. } \\
\text { Det var linet i en film, men ikke gresset. } \\
\text { There was the flax in a film, but not the grass. } \\
\text { Det var linet før, men ikke nå. } \\
\text { There was the flax before, but not now. }\end{array}$ \\
\hline 1 & smilet & the smile & $\begin{array}{l}\text { Broad } \\
\text { Narrow } \\
\text { AP-final }\end{array}$ & $\begin{array}{l}\text { Det var smilet i en film, men ikke i et stykke. } \\
\text { There was the smile in a film, but not in a play } \\
\text { Det var smilet i en film, men ikke tåren. } \\
\text { There was the smile in a film, but not the tear. } \\
\text { Det var smilet før, men ikke nå. } \\
\text { There was the smile before, but not now. }\end{array}$ \\
\hline
\end{tabular}




\begin{tabular}{|c|c|c|c|c|}
\hline Accent & Target Word & Gloss & Condition & Sentence \\
\hline 1 & slimet & the mucus & $\begin{array}{l}\text { Broad } \\
\text { Narrow } \\
\text { AP-final }\end{array}$ & $\begin{array}{l}\text { Det var slimet } i \text { en film, men ikke i et stykke. } \\
\text { There was the mucus in a film, but not in a play. } \\
\text { Det var slimet i en film, men ikke blodet. } \\
\text { There was the mucus in a film, but not the blood. } \\
\text { Det var slimet før, men ikke nå. } \\
\text { There was the mucus before, but not now. }\end{array}$ \\
\hline 1 & glimtet & the flash & $\begin{array}{l}\text { Broad } \\
\text { Narrow } \\
\text { AP-final }\end{array}$ & $\begin{array}{l}\text { Det var glimtet } \mathrm{i} \text { en film, men ikke i et stykke. } \\
\text { There was the flash in a film, but not in a play. } \\
\text { Det var glimtet i en film, men ikke brannen. } \\
\text { There was the flash in a film, but not the fire. } \\
\text { Det var glimtet før, men ikke nå. } \\
\text { There was the flash before, but not now. }\end{array}$ \\
\hline 2 & minne & memory & $\begin{array}{l}\text { Broad } \\
\text { Narrow } \\
\text { AP-final }\end{array}$ & $\begin{array}{l}\text { Det var et minne i en film, men ikke i et stykke. } \\
\text { There was a memory in a film, but not in a play. } \\
\text { Det var et minne i en film, men ikke en drøm. } \\
\text { There was a memory in a film, but not a dream. } \\
\text { Det var et minne før, men ikke nå. } \\
\text { There was a memory before, but not now. }\end{array}$ \\
\hline 2 & Line & (girl's name) & $\begin{array}{l}\text { Broad } \\
\text { Narrow }\end{array}$ & $\begin{array}{l}\text { Det var Line i en film, men ikke i et stykke. } \\
\text { Line was in a film, but not in a play. } \\
\text { Det var Line i en film, men ikke Anna. } \\
\text { Line was in a film, but not Anna. } \\
\text { Det var Line før, men ikke nå. } \\
\text { Line was there before, but not now. }\end{array}$ \\
\hline
\end{tabular}

\subsection{Appendix C: Experiment 1 Raw Results Averaged across Speakers}

Table 7. Average raw results for $\mathrm{F}_{0}$ maximum (semitones) by accent and focus realization

\begin{tabular}{lll}
\hline $\mathrm{F}_{0}$ max. & Broad & Narrow \\
\hline Accent 1 & 93.6 & 93.7 \\
Accent 2 & 93.7 & 93.5 \\
\hline
\end{tabular}

Table 8. Average raw results for $\mathrm{F}_{0}$ minimum (semitones) by accent and focus realization

\begin{tabular}{lll}
\hline $\mathrm{F}_{0}$ min. & Broad & Narrow \\
\hline Accent 1 & 86.8 & 86.2 \\
Accent 2 & 88.1 & 87.2 \\
\hline
\end{tabular}


Table 9. Average raw results for $\mathrm{F}_{0}$ maximum alignment (relative to word length) by accent and focus realization

\begin{tabular}{lll}
\hline $\mathrm{F}_{0}$ max. alignment & Broad & Narrow \\
\hline Accent 1 & -0.09 & -0.07 \\
Accent 2 & 0.03 & 0.11 \\
\hline
\end{tabular}

Table 10. Average raw results for $\mathrm{F}_{0}$ minimum alignment (relative to $\mathrm{VC}$ length) by accent and focus realization

\begin{tabular}{lll}
\hline $\mathrm{F}_{0}$ min. alignment & Broad & Narrow \\
\hline Accent 1 & 0.64 & 0.66 \\
Accent 2 & 1 & 1 \\
\hline
\end{tabular}

Table 11. Average raw results for $\mathrm{F}_{0}$ turning point alignment (relative to $\mathrm{VC}$ length) by accent and focus realization

\begin{tabular}{lll}
\hline $\mathrm{F}_{0}$ turning point & Broad & Narrow \\
\hline Accent 1 & 0.06 & 0.04 \\
Accent 2 & 0.5 & 0.5 \\
\hline
\end{tabular}

Table 12. Average raw results for slope of the rise by accent and focus realization

\begin{tabular}{lll}
\hline Rise & Broad & Narrow \\
\hline Accent 1 & 0.02 & 0.02 \\
Accent 2 & 0.018 & 0.017 \\
\hline
\end{tabular}

Table 13. Average raw results for slope of the fall by accent and focus realization

\begin{tabular}{lcc}
\hline Fall & Broad & Narrow \\
\hline Accent 1 & -0.04 & -0.04 \\
Accent 2 & -0.03 & -0.03 \\
\hline
\end{tabular}

Table 14. Average raw results for AP $\mathrm{H} \%$ height (semitones) by accent and focus realization

\begin{tabular}{lll}
\hline AP H\% height & Broad & Narrow \\
\hline Accent 1 & 92.1 & 93.7 \\
Accent 2 & 92.3 & 93.2 \\
\hline
\end{tabular}


Table 15. Average raw results for AP H\% timing (ms) by accent and focus realization

\begin{tabular}{lll}
\hline AP H\% timing & Broad & Narrow \\
\hline Accent 1 & 30 & 41 \\
Accent 2 & 31 & 40 \\
\hline
\end{tabular}

Table 16. Average raw results for boundary slope by accent and focus realization

\begin{tabular}{lll}
\hline Boundary slope & Broad & Narrow \\
\hline Accent 1 & 0.02 & 0.04 \\
Accent 2 & 0.02 & 0.03 \\
\hline
\end{tabular}

Table 17. Average raw results for long stressed vowels (ms) by accent and focus realization

\begin{tabular}{lll}
\hline Stressed vowel & Broad & Narrow \\
\hline Accent 1 & 162 & 182 \\
Accent 2 & 170 & 190 \\
\hline
\end{tabular}

Table 18. Average raw results for final vowels (ms) by accent and focus realization

\begin{tabular}{lll}
\hline Final vowel & Broad & Narrow \\
\hline Accent 1 & 63 & 80 \\
Accent 2 & 70 & 90 \\
\hline
\end{tabular}

5.4 Appendix D: Experiment 2 Raw Results Averaged across Speakers

Table 19. Average raw results for $F_{0}$ maximum (semitones) by accent and position

\begin{tabular}{lll}
\hline $\mathrm{F}_{0}$ max. & AP-medial & AP-final \\
\hline Accent 1 & 93.6 & 93.4 \\
Accent 2 & 93.7 & 93.4 \\
\hline
\end{tabular}

Table 20. Average raw results for $F_{0}$ minimum (semitones) by accent and position

\begin{tabular}{lll}
\hline $\mathrm{F}_{0}$ min. & AP-medial & AP-final \\
\hline Accent 1 & 86.8 & 87 \\
Accent 2 & 88.1 & 90 \\
\hline
\end{tabular}


Table 21. Average raw results for $F_{0}$ maximum alignment (relative to word length) by accent and position

\begin{tabular}{lll}
\hline $\mathrm{F}_{0}$ max. alignment & AP-medial & AP-final \\
\hline Accent 1 & -0.09 & 0.02 \\
Accent 2 & 0.03 & -0.01 \\
\hline
\end{tabular}

Table 22. Average raw results for $\mathrm{F}_{0}$ minimum alignment (relative to $\mathrm{VC}$ length) by accent and position

\begin{tabular}{lll}
\hline $\mathrm{F}_{0}$ min. alignment & AP-medial & AP-final \\
\hline Accent 1 & 0.64 & 0.63 \\
Accent 2 & 1 & 1 \\
\hline
\end{tabular}

Table 23. Average raw results for $\mathrm{F}_{0}$ turning point alignment (relative to VC length) by accent and position

\begin{tabular}{lll}
\hline $\mathrm{F}_{0}$ turning point & AP-medial & AP-final \\
\hline Accent 1 & 0.06 & 0.06 \\
Accent 2 & 0.5 & 0.5 \\
\hline
\end{tabular}

Table 24. Average raw results for slope of the rise by accent and position

\begin{tabular}{lll}
\hline Rise & AP-medial & AP-final \\
\hline Accent 1 & 0.02 & 0.02 \\
Accent 2 & 0.018 & 0.02 \\
\hline
\end{tabular}

Table 25. Average raw results for slope of the fall by accent and position

\begin{tabular}{lll}
\hline Fall & AP-medial & AP-final \\
\hline Accent 1 & -0.04 & -0.04 \\
Accent 2 & -0.03 & -0.03 \\
\hline
\end{tabular}

Table 26. Average raw results for AP $\mathrm{H} \%$ height (semitones) by accent and position

\begin{tabular}{lll}
\hline AP H\% height & AP-medial & AP-final \\
\hline Accent 1 & 92.1 & 90.7 \\
Accent 2 & 92.3 & 91.6 \\
\hline
\end{tabular}

$\begin{array}{lll} & & \\ \text { Phonetica 2017;74:193-230 } & \text { KOlly/Smiljanić }\end{array}$


Table 27. Average raw results for AP H\% timing (ms) by accent and position

\begin{tabular}{lll}
\hline AP H\% timing & AP-medial & AP-final \\
\hline Accent 1 & 30 & 26 \\
Accent 2 & 31 & 16 \\
\hline
\end{tabular}

Table 28. Average raw results for boundary slope by accent and position

\begin{tabular}{lll}
\hline Boundary slope & AP-medial & AP-final \\
\hline Accent 1 & 0.02 & 0.04 \\
Accent 2 & 0.02 & 0.04 \\
\hline
\end{tabular}

Table 29. Average raw results for long stressed vowels (ms) by accent and position

\begin{tabular}{lll}
\hline Stressed vowel & AP-medial & AP-final \\
\hline Accent 1 & 162 & 146 \\
Accent 2 & 170 & 145 \\
\hline
\end{tabular}

Table 30. Average raw results for final vowels (ms) by accent and position

\begin{tabular}{lll}
\hline Final vowel & AP-medial & AP-final \\
\hline Accent 1 & 63 & 72 \\
Accent 2 & 70 & 82 \\
\hline
\end{tabular}

\section{Acknowledgments}

The authors would like to thank Gjert Kristoffersen and his collaborators for their assistance with target words and stimuli. Thanks go also to Scott Myers, Megan Crowhurst and Harvey Sussman for comments, as well as to Katrin Schweitzer, and to Wim van Dommelen and all at NTNU. Many thanks also to the editor and reviewers for their very helpful feedback. The research used for this investigation was conducted with the support of the National Science Foundation Doctoral Dissertation Research Improvement Grant No. 1322700.

\section{References}

Abrahamsen JE (2004): Focus in the Herøy dialect; in Bruce G, Horne M (eds): Nordic Prosody IX. Lund, Lang, pp 9-18.

Abramson AS (1979): Lexical tone and sentence prosody in Thai. Proceedings of the International Congress of Phonetic Sciences, Copenhagen, pp 380-387.

Almberg J (2004): Tonal differences between four Norwegian dialect regions - some acoustic findings; in Bruce G, Horne M (eds): Nordic Prosody IX. Lund, Lang, pp 19-28.

Arvaniti A, Ladd DR, Mennen I (2006): Phonetic effects of focus and "tonal crowding" in intonation: evidence from Greek polar questions. Speech Commun 48:667-696.

Bannert R (1979): The effect of sentence accent on quantity. Proceedings of the 9th International Congress of Phonetic Sciences, Copenhagen, pp 253-259. 
Bannert R, Bredvad-Jensen A-C (1975): Temporal Organization of Swedish Tonal Accent: The Effect of Vowel Duration. Working Papers No 10. Lund, Department of Linguistics, Lund University, pp 1-36.

Bannert R, Bredvad-Jensen AC (1977): Temporal organization of Swedish tonal accents: the effect of vowel duration in the Gotland dialect. Working Papers No 15. Lund, Department of Linguistics, Lund University, pp $122-138$.

Beckman ME (1986): Stress and Non-Stress Accent. Dordrecht, Foris.

Beckman ME, Edwards J (1990): Lengthenings and shortenings and the nature of prosodic constituency; in Kingston J, Beckman M (eds): Papers in Laboratory Phonology I. Cambridge, Cambridge University Press, pp 179200.

Beckman ME, Edwards J (1994): Articulatory evidence for differentiating stress categories; in Keating PA (ed): Phonological Structure and Phonetic Form: Papers in Laboratory Phonology III. Cambridge, Cambridge University Press, pp 7-33.

Beckman ME, Pierrehumbert JB (1986): Intonational structure in English and Japanese. Phonol Yearb 3:255310.

Bjerrum M (1948): Felstedmaalets tonale accenter. Aarhus, Universitetsforlaget i Aarhus.

Boersma P, Weenink D (2011): Praat: doing phonetics by computer (computer program). Version 5.3.03. http:// www.praat.org/.

Bookcoverimgs.com. (2012): Map of regions of Norway. Digital image. http://norwords.com/settigang2/grammar/ regions/index.html/.

Bruce G (1977): Swedish Word Accents in Sentence Perspective. Travaux de l'Institut de Linguistique de Lund. Lund, Gleerup, vol 12.

Bruce G (1981): Tonal and temporal interplay. Working Papers 21. Lund, Department of Linguistics, Lund University, pp 49-60.

Bruce G (2005): Intonational prominence in varieties of Swedish revisited; in Ah Jun S (ed): Prosodic Typology: The Phonology of Intonation and Phrasing. Oxford, Oxford University Press, pp 410-429.

Cambier-Langeveld T, Turk AE (1999): A cross-linguistic study of accentual lengthening: Dutch vs English. J Phon 27:255-280.

Campbell N, Beckman M (1997): Accent, stress and spectral tilt. J Acoust Soc Am 101:3195.

Chafe WL (1976): Givenness, contrastiveness, definiteness, subjects, topics and point of view; in Li CN (ed): Subject and Topic. New York, Academic Press, pp 27-55.

Chen S-W, Wang B, Xu Y (2009): Closely related languages, different ways of realizing focus. Interspeech 2009, Brighton, pp 1007-1010.

Chen Y (2010): Post-focus $F_{0}$ compression: now you see it, now you don't. J Phon 38:517-525.

Cooper WE, Eady SJ, Mueller PR (1985): Acoustical aspects of contrastive stress in question-answer contexts. J Acoust Soc Am 77:2142-2156.

Derksen R (1966): Metatony in Baltic. Amsterdam, Rodopi.

Eefting W (1991): The effect of "information value" and "accentuation" on the duration of Dutch words, syllables, and segments. J Acoust Soc Am 89:412-424.

Elstad K (1978): Det nordnorske cirkumsflekstonemet; in Gårding E, Bruce G, Bannert R (eds): Nordic Prosody. Lund, pp 165-174.

Féry C, Kügler F (2008): Pitch accent scaling on given, new and focused constituents in German. J Phon 36:680703.

Fintoft K (1970): Acoustical Analysis and Perception of Tonemes in Some Norwegian Dialects. Oslo, Universitetsforlaget.

Fintoft K (1987): Toneme patterns in Norwegian and in Swedish dialects; in Channon R, Shockey L (eds): In Honor of Ilse Lehiste. Foris, Dordrecht, pp 33-50.

Fournier R, Verhoeven J, Swerts M, Gussenhoven C (2006): Perceiving word prosodic contrasts as a function of sentence prosody in two Dutch Limburgian dialects. J Phon 34:29-48.

Fretheim T (1981): Intonational phrasing in Norwegian. Nord J Linguist 4: 111-137.

Fretheim T (1982): Norwegian intonation patterns in discourse perspective: is there a neutral intonation? In Fretheim T, Hellan L (eds): Papers from the Sixth Scandinavian Conference of Linguistics. Trondheim, Tapir,pp 193204.

Fretheim T (1987a): Phonetically low tone-phonologically high tone, and vice versa. Nord J Linguist 10:35-58.

Fretheim T (1987b): Pragmatics and intonation; in Verschueren J, Bertuccelli-Papi M (eds): The Pragmatic Perspective. Amsterdam, Benjamins, pp 395-420.

Fretheim T (1991): Intonational phrases and syntactic focus domains; in Verschueren J (ed): Levels of Linguistic Adaptation. Amsterdam, Benjamins, pp 81-112.

Fretheim T, Nilsen RA (1989): Terminal rise and rise-fall tunes in East Norwegian intonation. Nord J Linguist 12:155-181.

Gårding E (1973): The Scandinavian word accents. Working Papers 8. Lund, Phonetics Laboratory, Lund University.

Gårding E (1993): Focal domains and their tonal manifestations in some Swedish dialects; in Grandström B, Nord L (eds): Nordic Prosody VI. Stockholm, Almquist \& Wiksell, pp 65-76.

Gårding E, Lindblad P (1975): Constancy and variation in Swedish word accent patterns. Working Papers 7. Lund, Phonetics Laboratory, Lund University, pp 36-100. 
Grabe E, Post B, Nolan F, Farrar F (2000): Pitch accent realization in four varieties of British English. J Phon 27:161-185.

Google Maps (2016): Norway. https://www.google.at $/ \mathrm{maps} / @ 63.0062863,8.7147647,8 \mathrm{z} / \mathrm{data}=$ !3m1!4b1!4m2!6m1!1szSvGrFZM0LUI.k0HftQJAEgOk?hl = en.

Gussenhoven C (1984): On the Grammar and Semantics of Sentence Accents. Dordrecht, Foris.

Gussenhoven C (2004): The Phonology of Tone and Intonation. Cambridge, Cambridge University Press.

Gussenhoven C (2005): Semantics of prosody; in Brown K (ed): Encyclopedia of Language and Linguistics, ed 2. Oxford, Elsevier, pp 170-173.

Gussenhoven C, Bruce G (1999): Word prosody and intonation; in van der Hulst H (ed): Word Prosodic Systems in the Languages of Europe. Berlin, Mouton de Gruyter, pp 233-271.

Gussenhoven C, van der Vliet P (1999): The phonology of tone and intonation in the Dutch dialect of Venlo. J Linguist 35:99-135.

Hadding-Koch K (1961): Acoustico-Phonetic Studies in the Intonation of Southern Swedish. Lund, Gleerup.

Hadding-Koch K (1962): Notes on the Swedish word tones. 4th International Congress of Phonetic Sciences, Helsinki 1961, pp 630-638.

Haugen E, Joos M (1952): Tone and intonation in East Norwegian. Acta Philol Scand 22:41-64.

Hayes B, Lahiri A (1991): Bengali intonational phonology. Nat Lang Linguist Theory 9:47-96.

Heldner M, Strangert E (2001): Temporal effects of focus in Swedish. J Phon 29:329-361.

Hualde JI (1991): Basque Phonology. London, Routledge.

Hualde JI (2012): Two Basque accentual systems and the notion of pitch-accent language. Lingua 122:1335-1351.

Hyman L (2009): How (not) to do phonological typology: the case of pitch-accent. Lang Sci 31:213-238.

Karins AK (1996): The Prosodic Structure of Latvian; doctoral dissertation, University of Pennsylvania.

Karlsson A, House D, Svantesson J-A, Tayanin D (2010): Influence of lexical tones on intonation in Kammu. Interspeech 2010, Chiba, pp 1740-1743.

Katz J, Selkirk E (2011): Contrastive focus vs discourse-new: evidence from phonetic prominence in English. Language 87:771-816.

Kelly NE (2015): An Experimental Approach to the Production and Perception of Norwegian Tonal Accent; doctoral dissertation, University of Texas at Austin.

Kelly NE, Schweitzer K (2015): Examining Lexical Tonal Contrast in Norwegian Using Intonation Modelling. 18th International Congress of Phonetic Sciences, Glasgow, August 2015.

Kelly NE, Smiljanić R (2014): The effect of focus on Norwegian tonal accent. Proceedings of Tonal Aspects of Languages 2014, Nijmegen, pp 95-99.

Kim G-R (1988): The Pitch Accent System of the Taegu Dialect of Korean with Emphasis on Tone Sandhi at the Phrasal Level; doctoral dissertation, University of Hawaii, Honolulu.

Koreman J, Andreeva B, Barry WJ, Van Dommelen W, Sikveland R (2009): Cross-language differences in the production of phrasal prominence in Norwegian and German. Nordic Prosody: Proceedings of the Xth Conference, Helsinki, August 4-6, 2008.

Kristoffersen G (2000): The Phonology of Norwegian. Oxford, Oxford University Press.

Kristoffersen G (2003): The tone bearing unit in Swedish and Norwegian tonology; in Galberg Jacobsen H, Bleses D, Madsen TO, Thomsen P (eds): Take Danish - For Instance. Linguistic Studies in Honour of Hans Basbøll. Odense, University Press of Southern Denmark, pp 189-198.

Kristoffersen G (2006a): Dialect variation in East Norwegian tone. Unpublished manuscript.

Kristoffersen G (2006b): Tonal melodies and tonal alignment in East Norwegian; in Bruce G, Horne M (eds): Nordic Prosody IX. Frankfurt am Main, Lang.

Ladd DR (1978): The Structure of Intonational Meaning. Ithaca, Cornell University.

Ladd DR (1996): Intonational Phonology. Cambridge, Cambridge University Press.

Ladd DR, Schepman A, White L, Quarmby LM, Stackhouse R (2009): Structural and dialectal effects on pitch peak alignment in two varieties of British English. J Phon 37:145-161.

Lin M (2004): On production and perception of boundary tone in Chinese intonation. Proceedings of Tonal Aspects of Languages 2004, Beijing, pp 125-130.

Lorentz O (1981): Adding tone to tone in Scandinavian dialects; in Fretheim T (ed): Nordic Prosody II. Trondheim, Tapir, pp 166-180.

Mixdorff H, Andreeva B, Koreman J (2010): Quantitative modelling of Norwegian tonal accents in different focus conditions. Proceedings of Speech Prosody 2010, Chicago.

Morén B, Zsiga E (2006): The lexical and post-lexical phonology of Thai tones. Nat Lang Linguist Theory 24:113178.

Nilsen RA (1989): On prosodically marked information structure in spoken Norwegian. University of Trondheim Working Papers in Linguistics 7. Trondheim, University of Trondheim.

Nilsen RA (1992): Intonasjon i interaksjon - sentrale spørsmål i norsk intonologi; doctoral dissertation, University of Trondheim.

Peters J (2007): Bitonal lexical pitch accents in the Limburgian dialect of Borgloon; in Riad T, Gussenhoven C (eds): Tones and Tunes. Berlin, Mouton de Gruyter, vol 1: Typological and Comparative Studies in Word and Sentence Prosody, pp 167-198.

Peters J, Hanssen J, Gussenhoven C (2014): The phonetic realization of focus in West Frisian, Low Saxon, High German, and three varieties of Dutch. J Phon 46:185-209. 
Pierrehumbert J (1980): The Phonology and Phonetics of English Intonation; doctoral dissertation, MIT, Cambridge.

Pierrehumbert J (2000): Tonal elements and their alignment; in Horne M (ed): Prosody: Theory and Experiment. Studies Presented to Gösta Bruce. Dordrecht, Kluwer, pp 11-26.

Pierrehumbert J, Beckman M (1988): Japanese Tone Structure. Cambridge, MIT Press.

Prieto P (2014): The intonational phonology of Catalan; in Jun S-A (ed): Prosodic Typology 2. The Phonology of Intonation and Phrasing. Oxford, Oxford University Press, pp 43-80.

Prieto P, D'Imperio M, Gili Fivela B (2005): Pitch accent alignment in Romance: primary and secondary associations with metrical structure. Lang Speech 48:359-396.

Prieto P, van Santen J, Hirschberg J (1995): Tonal alignment patterns in Spanish. J Phon 23:429-451.

R Development Core Team (2008): R: a language and environment for statistical computing. R Foundation for Statistical Computing, Vienna. http://www.R-project.org.

Remijsen B (2002): Word-Prosodic Systems of Raja Ampat Languages; doctoral dissertation, Leiden University.

Remijsen B (2013): Tonal alignment is contrastive in falling contours in Dinka. Language 89:297-327.

Remijsen B, Gwado Ayoker O (2014): Evidence for contrastive tonal alignment in Shilluk. Proceedings of Tonal Aspects of Languages 2014, Nijmegen, pp 6-9.

Remijsen B, van Heuven VJ (2005): Stress, tone and discourse prominence in the Curaçao dialect of Papiamentu. Phonology 22:205-235.

Riad T (1998): Towards a Scandinavian accent typology; in Kehreirr W, Wiese R (eds): Phonology and Morphology of the Germanic Languages. Linguistische Arbeiten 386. Tübingen, Niemeyer, pp 77-109.

Riad T (2006): Scandinavian accent typology. Sprachtyp Univ Forsch Berlin 59:36-55.

Rooth M (1985): Association with Focus; doctoral dissertation, University of Massachusetts, Amherst.

Schepman A, Lickley R, Ladd DR (2006): Effects of vowel length and "right context" on the alignment of Dutch nuclear accents. J Phon 34:1-28.

Scholz F (2012): Tone Sandhi, Prosodic Phrasing, and Focus Marking in Wenzhou Chinese; doctoral dissertation, Leiden University.

Segerup M (2003): Word accent gestures in West Swedish; in Heldner M (ed): Proceedings from Fonetik 2003, Phonum 9. Umeå, University of Umeå, pp 25-28.

Segerup M (2004): Gothenburg Swedish word accents: a fine distinction; in Branderud P, Traunmüller H (eds): Proceedings from Fonetik 2004 Stockholm, University of Stockholm, pp 28-31.

Selkirk E (2008): Contrastive focus, givenness and the unmarked status of "discourse-new". Acta Linguist Hung 55:331-346.

Senn A (1966): Handbuch der litauischen Sprache. Heidelberg, Carl-Winter-Universitätsverlag.

Shue Y-L, Shattuck-Hufnagel S, Iseli M, Jun S, Veilleux N, Alwan A (2008): Effects of intonational phrase boundaries on pitch-accented syllables in American English. Proceedings Interspeech, Brisbane, pp 873-876.

Silverman K, Pierrehumbert J (1990): The timing of prenuclear high accents in English; in Kingston J, Beckman M (eds): Papers in Laboratory Phonology I: Between the Grammar and Physics of Speech. Cambridge, Cambridge University Press, pp 72-106.

Sluijter AMC, van Heuven VJ (1996): Acoustic correlates of linguistic stress and accent in Dutch and American English. Proceedings of the 4th International Conference on Spoken Language Processing (ICSLP), Philadelphia.

Smiljanić R (2003): Lexical and pragmatic effects on pitch range and low tone alignment in two dialects of Serbian and Croatian. Proceedings of the 39th Regional Meeting of the Chicago Linguistic Society, Chicago, pp 520-539.

Smiljanić R (2006): Early vs late focus: pitch-peak alignment in two dialects of Serbian and Croatian; in Goldstein L, Whalen DH, Best C (eds): Papers in Laboratory Phonology 8. Berlin, Mouton, pp 495-518.

Storm J (1884): Norvegia. Tidsskrift for det norske folks maal og minder. Kristiania, Grøndahl and Søn.

Teig AH (2001): Can phonetically high pitch represent phonologically low tone? Evidence from East Norwegian raised background domains; in Van Dommelen WA, Fretheim T (eds): Nordic Prosody: Proceedings of the VIIIth Conference, Trondheim, August 19-21, 2000. Frankfurt, Lang, pp 213-225.

Van Dommelen WA (2002): Toneme realization in two North Norwegian dialects. Proc Fon 44:21-24.

Van Dommelen WA, Nilsen RA (2003): Toneme realization in two East Norwegian dialects. Proc Fon PHONUM 9:21-24.

Vanvik A (1957): Norske tonelag. Maal og Minne, pp 92-102.

Wetterlin A (2010): Tonal Accents in Norwegian: Phonology, Morphology and Lexical Specification. Berlin, de Gruyter.

$\mathrm{Xu}$ Y (1999): Effects of tone and focus on the formation and alignment of $\mathrm{f}_{0}$ contours. J Phon 27:55-105.

Xu Y, Xu CX (2005): Phonetic realization of focus in English declarative intonation. J Phon 33:159-197.

Xu Y (2013): ProsodyPro - a tool for large-scale systematic prosody analysis. Proceedings of Tools and Resources for the Analysis of Speech Prosody (TRASP 2013), Aix-en-Provence, pp 7-10.

Yip M (2002): Tone. Cambridge, Cambridge University Press.

Zhang L, Zu Y-Q, Yan R-Q (2006): Focus, lexical stress and boundary tone: interaction of 3 prosodic features. Chinese Spoken Language Processing: Proceedings of the 5th International Symposium (ISCSLP 2006), Singapore. 